2016

\title{
Shattering the Glass Ceiling in International Adjudication
}

Nienke Grossman

University of Baltimore School of Law, ngrossman@ubalt.edu

Follow this and additional works at: http://scholarworks.law.ubalt.edu/all_fac

Part of the Courts Commons, International Law Commons, and the Law and Gender Commons

\section{Recommended Citation}

Shattering the Glass Ceiling in International Adjudication, 56 Va. J. Int'l L. (forthcoming 2016)

This Article is brought to you for free and open access by the Faculty Scholarship at ScholarWorks@University of Baltimore School of Law. It has been accepted for inclusion in All Faculty Scholarship by an authorized administrator of ScholarWorks@University of Baltimore School of Law. For more information, please contact snolan@ubalt.edu. 


\title{
SHATTERING THE GLASS CEILING IN INTERNATIONAL ADJUDICATION
}

\author{
Nienke Grossman*
}

The Article shows that women are found in dramatically low numbers on the benches of the majority of the world's most important international courts, analyzes the causes of this phenomenon and proposes and evaluates solutions. It establishes that the number of women in the pool of potential judges does not appear to dictate how many women become international judges. It shows, too, that when selection procedures are closed and opaque, and there is no quota or aspirational target for a sex-balanced bench, women obtain international judgeships in disproportionately low numbers. On the other hand, when a quota or aspirational target exists, benches are more balanced. Finally, the Article suggests and evaluates concrete reforms to selection procedures on international courts to remedy this problem, including greater transparency and openness in selection procedures, aspirational targets for the participation of women on the bench and quotas. It is the first article to explore the relationship between selection procedures and sex representativeness outcomes on international courts.

* Associate Professor, University of Baltimore School of Law; AB, Harvard College; JD, Harvard Law School; LLM, Georgetown University Law Center. The author benefitted from insightful comments received at the AALS Transnational Perspectives on Equality Law Conference, the Université libre de Bruxelles' "Le juge est une femme" conference, the Junior International Law Scholars Association meeting at the University of California-Berkeley, and the New York University Colloquium on International Law and Justice, as well as from Karen Alter, José Alvarez, Harlan Grant Cohen, Susan Franck, Claudio Grossman, Benedict Kingsbury, Judith Resnik, Darren Rosenblum and Erik Voeten. She is very grateful for assistance from Adeen Postdar, Harvey Morrell, Yasmine Akkad, Jillian Bokey, Mattanaiah Ezeigbo, Bridgette Lane, and Maria Surdokas, and for summer research support from the University of Baltimore School of Law. 


\section{TABLE OF CONTENTS}

Introduction 3

I. How Balanced Are International Court Benches? ............................................. 12

II. Why so few women?............................................................................... 24

A. The Limited Pool .................................................................................. 24

B. There's an opening? The opacity of national nomination

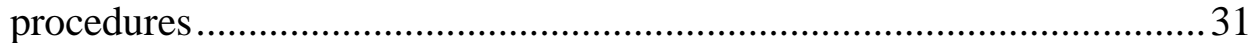

1. Group 1: Little Guidance or Transparency................................... 32

2. Group 2: Greater Amount of Guidance and Transparency................. 37

3. Group 3: No National Nomination Procedure .................................. 44

4. Conclusions on National Nominations .......................................... 45

C. Elections - May the Best Candidate Win? ............................................. 48

1. Group 1: Quotas and Screening ................................................ 49

2. Group 2: Screening and Ranking, But Little Statutory

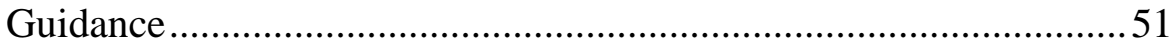

3. Group 3: Some Statutory Guidance, But No Screening ...................53

4. Group 4: No Screening and Little Statutory Guidance .....................54

D. Sex Representation Requirements .................................................58

E. Summarizing the Reasons for the Paucity of Women on the Bench........62 62

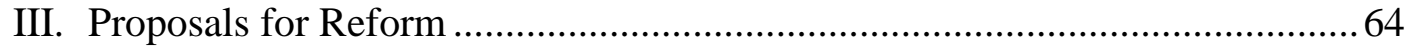

A. Enhance Candidate Selection Procedures .............................................65

B. Aspirational Targets or Temporary Mandatory Quotas..........................6 69

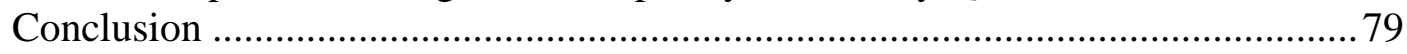




\section{INTRODUCTION}

Twenty-four years ago, Hillary Charlesworth, Christine Chinkin and Shelley Wright wrote a path-breaking feminist critique of international law and institutions in the American Journal of International Law. ${ }^{1}$ While applying feminist methodologies to international law and institutions is no longer a novel endeavor, serious questions remain about the extent to which the structures and content of international law continue to "privilege men," despite the elapse of almost a quarter century. How much international law has made a difference to women and girls' rights is questionable, particularly when in many parts of the globe they continue to suffer from physical abuse at the hands of both state and non-state actors, are prevented from going to school, married off or trafficked as children, and used as child soldiers. Progress in integrating women into international legal institutions is uneven at best.

For example, the influential 34-member International Law Commission and 11-member Inter-American Juridical Committee contained only 2 female members each in June $2014 .^{2}$ The UN human rights treaty bodies show ghettoization of women on the Committee on the Elimination of Discrimination Against Women, where women made up 22 of 23 members, and on the Committee on the Rights of the Child, where they accounted for 11 of 18 members. ${ }^{3}$ Yet women made up only $10 \%$ of the UN Committee on Enforced Disappearances, ${ }^{4} 22 \%$ of the UN Human Rights Committee, the Committee on Economic, Social and Cultural Rights, and the Committee on the Elimination of Racial Discrimination. ${ }^{5}$

${ }^{1}$ Hilary Charlesworth, Christine Chinkin, and Shelley Wright, Feminist Approaches to International Law, 85 AM. J. INT'L L. 613 (1991).

2 Membership, available at http://legal.un.org/ilc/ilcmembe.htm (last visited June 26, 2014); Members,

http://www.oas.org/en/sla/iajc/members.asp (last visited June 26, 2014). Membership, at http://www.ohchr.org/EN/HRBodies/CEDAW/Pages/Membership.aspx (last visited June 26, 2014); Membership, at http://www.ohchr.org/EN/HRBodies/CRC/Pages/Membership.aspx (last visited June 26, 2014).

4 Members of the Committee on Enforced Disappearances, at http://www.ohchr.org/EN/HRBodies/CED/Pages/Membership.aspx (last visited June 26, 2014).

5

Membership, available

at http://www.ohchr.org/EN/HRBodies/CCPR/Pages/Membership.aspx (last 
Only the Committee on the Rights of Persons with disabilities was relatively balanced; 7 out of 18 of its members were women. ${ }^{6}$ At a 2014 International Council for Commercial Arbitration conference, self-reports by participants established that $82.4 \%$ of those serving as arbitrators were men, while only $17.6 \%$ were women. ${ }^{7}$ Only four female lawyers appeared before the International Court of Justice more than once between 1999 and 2012, while 59 men appeared more than once during the same period. ${ }^{8}$ The four female lawyers accounted for only $2.9 \%$ of the speaking time during the fourteen year period studied. ${ }^{9}$

On most international courts and tribunals, the focus of this article, men continue greatly to outnumber women on the bench. International courts decide the scope of our human rights, what individuals should be held accountable for atrocity crimes, what natural resources belong to which states, when environmental concerns should trump trade rules and when the use of force is allowed. They find facts, discern relevant rules of international law and apply them, filling gaps when necessary. International judges come from all over the world, but they do not appear to reflect vast swathes of the world's people. ${ }^{10}$ Most international court judges

visited June 27, 2014); Membership, at
http://www.ohchr.org/EN/HRBodies/CESCR/Pages/Membership.aspx (last visited June 26, 2014). Three out of 14 of the members of the Committee on Migrant Workers were women. Membership, at http://www.ohchr.org/EN/HRBodies/CMW/Pages/Membership.aspx (last visited June 26, 2014). Women made up 30\% of the UN Committee Against Torture. Membership, available at http://www.ohchr.org/EN/HRBodies/CAT/Pages/Membership.aspx (last visited June 27, 2014).

6

Membership, at http://www.ohchr.org/EN/HRBodies/CRPD/Pages/Membership.aspx (last visited June 26, 2014).

${ }^{7}$ Susan Franck et al., The Diversity Challenge: Exploring the 'Invisible College' of International Arbitration 17 (on file with author).

${ }^{8}$ Shashank Kumar and Cecily Rose, A Study of Lawyers Appearing Before the International Court of Justice, 25 EuRO. J. INT'L L. 893, 904. (2014).

${ }^{9}$ Id.

${ }^{10}$ A 2006 study found that of 215 international court judges, 63\% came from civil law countries, $14 \%$ from common law countries, and $23 \%$ came from mixed common law/civil law, Islamic or local customary law blended with civil or common law traditions. DANIEL TERRIS, CESARE P.R. ROMANO \& LEIGH SWIGART, THE INTERNATIONAL JUDGE: AN INTRODUCTION TO THE 
studied law in the top universities in their countries, while many also studied international law, and a large majority had graduate or doctoral degrees from top elite universities such as Harvard University, Columbia University, the University of Cambridge, the University of London, Oxford University, the University of Paris and the University of Moscow. ${ }^{11}$ Judges frequently have decades of experience and generally hale from three career paths: the national judiciary, academia or civil service in international organizations or for their own states as diplomats. ${ }^{12}$ The percentage of international court judges from indigenous or poor backgrounds, minority groups within their own countries or having disability status appears to be relatively unquestioned and unknown.

We can say with certainty, however, that a great majority of international courts are not representative when it comes to gender. ${ }^{13}$ On eight international courts surveyed with no representativeness requirements built into their selection procedures, only $15 \%$ of judges were women in mid-2015. ${ }^{14}$ On the five courts with either aspirational representativeness language or mandatory targets, $33 \%$ were women, however. ${ }^{15}$ Since 1998 , an average of $13 \%$ of judges on international courts without representativeness requirements have been women, while, on average, $31 \%$ of judges on courts with such mandates or aspirations were women. ${ }^{16}$ Courts without representativeness requirements include the Inter-American Court of Human Rights (one woman on a seven member bench), the International Tribunal for the Law of the Sea (one woman on a 21-member

Men AND Women Who DeCide THE WorLD's CASES 17 (2007).

${ }^{11} I d$. at $17-18$.

${ }^{12} I d$. at 20 . The study found that $40 \%$ came from academia, $33 \%$ were professional national judges, and about $28 \%$ were either national or international civil servants. Id. See also Erik Voeten, The Politics of International Judicial Appointments, 9 CHI. J. INT'L L. 387, 390 (2008).

${ }^{13}$ See Nienke Grossman, Sex on the Bench: Do Women Judges Matter to the Legitimacy of International Courts?, 12 CHI. J. INT'L L. 647, 654 (2012) [hereinafter Grossman I]; see Part I, infra.

${ }^{14}$ See Part I, infra.

15 These courts include the European Court of Human Rights, the African Court on Human and Peoples' Rights, the International Criminal Court, and only ad litem judges for the International Criminal Tribunals for the Former Yugoslavia and Rwanda.

${ }^{16}$ These percentages were obtained by adding up the total number of slots in which women judges served every year since the courts were established and dividing it by the total number of slots in which both male and female judges served every year since establishment. 
bench), and the World Trade Organization's Appellate Body (one woman on a 7-member bench).

These statistics establish that Charlesworth, Chinkin and Wright's critique of international institutions remains relevant for most international courts. While some may take for granted that sex representativeness on the bench, or generally approximating the ratio of the sexes in the general population, is worth aspiring to for a number of reasons, others appear skeptical about its importance. A prominent commentary on the Rome Statute of the International Criminal Court described the requirement for "fair representation" on the bench as a "gesture in the direction of political correctness." ${ }^{" 17}$ There are on-going debates on whether a representativeness requirement should be applied to investment panels in the Transatlantic Trade and Investment Partnership, ${ }^{18}$ and whether commissioner and judicial diversity matters for the Inter-American Commission and Court of Human Rights. ${ }^{19}$ Judges and individuals involved in judicial selection on the International Court of Justice and the International Criminal Court have expressed mixed views about the importance of sex representation requirements. $^{20}$ While the requirements for legal, linguistic and geographical diversity are widely accepted, "attitudes towards gender balance are generally much more ambivalent." 21

Yet the paucity of women judges on most international court benches is worrisome for a number of reasons. First, it affects both the normative and sociological legitimacy of international courts. ${ }^{22}$ Scholars of normative legitimacy ask what characteristics ought to be present for a court's authority to be justified, while students of sociological legitimacy focus on what drives perceptions of justified authority. ${ }^{23}$ Legitimacy rests

${ }^{17}$ John R.W.D. Jones, Composition of the Court, in ANTONIO CASSESE, Paolo Gaeta and John R.W.D. Jones (eds.), The Rome Statute of the INTERNATIONAL CRIMINAL COURT: A COMMENTARY 255 (2002).

${ }^{18}$ Email discussion on OGEMID listserv (July 1-2, 2014) (on file with author).

${ }^{19}$ CEJIL, Proceso de selección de integrantes de la comisión y la corte inter-americana de derechos humanos: reflexiones hacia una reforma (2014).

20 Ruth Mackenzie et al., Selecting International Judges: Principle, Process, AND Politics 1 (2010) [hereinafter Selecting INTERNATIONAL JUDGES].

${ }^{21} I d$. at $48-49$.

${ }^{22}$ See Grossman I, supra note 13, at 652.

${ }^{23}$ Daniel Bodansky, The Legitimacy of International Governance: A Coming Challenge for 
in part on the impartiality of a court. ${ }^{24}$ If men and women approach judging differently, whether based on nature or nurture, a homogeneous bench is inherently biased. Few studies of the gender effect of judging on international courts exist, due in part to the paucity of women on the bench. ${ }^{25}$ But one study showed that women judges are much more likely to rule in favor of jurisdiction in International Centre for Settlement of Investment Disputes ICSID cases than men. ${ }^{26}$ Another established that International Criminal Tribunal for the Former Yugoslavia panels with female judges imposed more severe sanctions on defendants who assaulted females, while men imposed more severe sanctions on defendants who assaulted men. ${ }^{27}$ Judge Navanethem Pillay, the only woman on a panel hearing Jean Paul Akayesu's case before the International Criminal Tribunal for Rwanda, is credited with vigorously questioning witnesses about sexual violence, ultimately resulting in the first conviction of an individual for the crime against humanity of rape and of genocide founded on rape. ${ }^{28}$ And several renowned female international court judges have

International Environmental Law?, 93 AM. J. INT'L L. 596, 601 (1999); Nienke Grossman, Legitimacy and International Adjudicative Bodies, 41 GEO. WASH. INT'L L. REV. 107, 116 (2009) [hereinafter Grossman II].

${ }^{24}$ See BRIAN BARRY, JUSTICE AS IMPARTIALITY 17-18 (1995); see also David Luban, Fairness to Rightness: Jurisdiction, Legality, and the Legitimacy of International Criminal Law, Working Paper No. 1154117, *13 (Georgetown University Law Center, 2008), available at http://papers.ssrn.com/sol3/papers.cfm?abstract_id=1154177; TOM R. TYLER, LEGITIMACY AND CRIMINAL JUSTICE: INTERNATIONAL PERSPECTIVES 4 (Tom R. Tyler, ed. 2007); Grossman II, supra note 23, at 129.

25 See Kimi L. King \& Megan Greening, Gender Justice of Just Gender? The Role of Gender in Sexual Assault Decisions at the International Criminal Tribunal for the Former Yugoslavia, 88 SoC. SCI. Q. 1049, 1050 n. 2 (2007) (examining the relationship between sentence length and sex of the judge and victim, but not including the ICTR because "there are too few [women judges] to conduct empirical analysis and virtually all the guilty defendants received life sentences.").

${ }^{26}$ Michael Waibel \& Yanhui Wu, Are Arbitrators Political?, ASIL Research Forum *35 (UCLA Nov. 5, 2011), online at http://www.asil.org/midyearmeeting/pdfs/papers/November_5_2pm/Are\%2 0Arbitrators\%20Political.pdf (visited Nov. 18, 2011).

${ }^{27}$ King \& Greening, supra note 25, at 1049-1050, 1065-66.

${ }^{28}$ Richard J. Goldstone, Prosecuting Rape as a War Crime, 34 CASE W. RES. J. INT'L L. 277, 282 (2002); see also Navanethem Pillay, Equal Justice for Women: A Personal Journey, 50 ARIz. L. REV. 657, 665-66 (2008); 
made the point that women bring a different set of life experiences to the bench than men do. ${ }^{29}$

Even if men and women do not think differently, if they can overcome their differences, or if there is no essence unique to women as a group or men as a group in the first place, sex unrepresentativeness can still harm perceptions of legitimacy. For example, non-governmental organizations and some states argued for including women on the benches of post-WWII international criminal tribunals because they believed women might make a difference in the prosecution of international crimes against women. $^{30}$ Constituencies, especially those traditionally excluded from power, may continue to believe unrepresentative courts are biased against them. South Africa could not have countenanced an all-white all-male judiciary, even if all the judges were "cured" of racism and sexism the day after Apartheid ended. In light of Third World critiques of international law and institutions, it is not surprising that the drafters of the World Trade Organization's Dispute Settlement Understanding chose to give developing states the right to demand adjudicators from developing countries on dispute settlement panels hearing cases involving both developing and developed states. ${ }^{31}$ The exclusion of women from international law-making institutions historically has raised similar concerns among feminist

Prosecutor v. Akayesu, Judgment, Case No. ICTR-96-4, paras. 696, 731 (ICTR, Sept. 2, 1988); José E. Alvarez, Lessons from the Akayesu Judgment, 5 ILSA J. INT'L \& COMP. L. 359 ,362-63 (1999).

29 See e.g., Patricia Wald, Six Not-So-Easy Pieces: One Woman's Journey to the Bench and Beyond, 36 U. TOLEDo L. REV. 979, 989 (2005); Patricia Wald, What Do Women Want from International Criminal Justice? To Help Shape the Law (Intlawgrrls Oct. 5, 2009)), online at http://intlawgrrls.blogspot.com2009/10/what-do-women-want-frominternational-law.html (last visited Oct. 12, 2011); TERRIS, ET AL., supra note 10, 48, 186-87 (containing comments by former ICC Judge Navanethem Pillay and former Inter-American Court of Human Rights Judge Cecilia Medina Quiroga).

${ }^{30}$ See Grossman I, supra note 13, at 661-64.

${ }^{31}$ Understanding on Rules and Procedures Governing the Settlement of Disputes, art. 8(10), Marrakesh Agreement Establishing the World Trade Organization, Annex 2, Legal Instruments-Results of the Uruguay Round, 33 I.L.M. 1125, 1232 (1994) [hereinafter Dispute Settlement Understanding] ("when a dispute is between a developing country Member and a developed country Member the panel shall, if the developing country Member so requests, include at least one panelist from a developing country Member"). 
scholars. $^{32}$

Democratic legitimacy provides another compelling reason for sex representation on international courts: those affected should be represented among decision-makers. International courts exercise public authority by interpreting and shaping international law. "The de facto lawmaking role played by international judges cannot be denied." 33 This authority requires justification, and democratic values such as representation provide a meaningful justification. ${ }^{34}$ Both women and men are the beneficiaries of the work of international courts and should be involved in judicial decisionmaking for these institutions to possess justified authority.

There are, of course, other justifications beyond legitimacy, for seeking sex representation on the bench. The presence of members of previously excluded groups in positions of influence may create mentorship opportunities and role models for others; it may give previously excluded groups the sense that they too can succeed. One study found that more female members of parliament correlates with more discussion of politics by both adolescent and adult women, increased participation in politics by adult women, and a greater intention to participate in politics among adolescent girls. ${ }^{35}$ The same phenomenon may exist in other environments.

${ }^{32}$ See Hilary Charlesworth \& Christine Chinkin, Boundaries of INTERNATIONAL LAW: A FEMINIST ANALYSIS 308 (2000).

${ }^{33}$ TERRIS ET AL., supra note 10, at 115-17 (discussing a number of different examples, ranging from the European and Inter-American human rights courts' contribution to the development of human rights law "far beyond what the original drafters [of the respective conventions] might have conceived," to the role of the European Court of Justice in European integration, to the WTO Appellate Body's inclusion of other areas of international law within its jurisdiction); see also Armin von Bogdandy \& Ingo Venzke, Beyond Dispute: International Judicial Institutions as Lawmakers, 12 GERMAN L. J. 979, 979 (2011) (stating that international judicial decisions influence future decisions); Nienke Grossman, The Normative Legitimacy of International Courts, 86 TEMPLE L. REV. 61, 6876 (2013) [hereinafter Grossman III] (explaining how international courts influence the development of law and politics).

${ }^{34}$ Gráinne De Búrca, Developing Democracy Beyond the State, 46 Colum. J. TRAnSNAT'L L. 221, 226-27 (2008). Armin von Bogdandy and Ingo Venzke, On the Democratic Legitimation of International Judicial Lawmaking, 12 GER. L. J. 1341, 1343 (2011).

${ }^{35}$ Christina Wolbrecht \& David E. Campbell, Leading by Example: Female Members of Parliament as Political Role Models, 51 AM. J. Poli. SCI. 921-39 (2007); see also, e.g., Kijana Crawford \& Danielle Smith, The 
And having diverse judges can have ripple effects on homogenous counsel as well. For example, appearing with an all-male team of lawyers before a Court with several women judges, some of whom may have called for greater diversity in the bar, may be ill-advised.

Further, states are under an international legal obligation to grant men and women equal access to employment on international court benches. The United Nations Charter specifies the United Nations, "shall place no restrictions on the eligibility of men and women to participate in any capacity and under conditions of equality in its principal and subsidiary organs." ${ }^{36}$ Courts affiliated with the United Nations in some way or another include the International Court of Justice (primary judicial organ), the tribunals for the former Yugoslavia and Rwanda (created by Security Council Resolutions), and the International Criminal Court (through referral and deferral by the Security Council), among others. In addition, the International Covenant on Civil and Political Rights indicates that States Parties "undertake to ensure the equal rights of men and women to the enjoyment of all civil and political rights set forth in the present Covenant," including the right and opportunity to take part in the conduct of public affairs and to have access "on general terms of equality" to public service. ${ }^{37}$

The Convention on the Elimination of Discrimination against Women provides further evidence of state's obligation to take steps to ensure the participation of women at all levels of governance. States Parties are obligated to "take all appropriate measures to eliminate discrimination against women in the political and public life of the country and, in particular, shall ensure to women, on equal terms with men, the right... to participate in the formulation of government policy and the implementation hereof and to hold public office and perform all public functions at all levels of government." 38 International courts fall within the scope of the

We and the US: Mentoring African American Women, 36 J. BLACK STUDS. 52 (2005) (referring to the importance of mentoring to the career development of African American female administrators in higher education).

${ }^{36}$ United Nations Charter, art. 8. The Preamble "reaffirm[s] faith in fundamental human rights, in the dignity and worth of the human person, in the equal rights of men and women and of nations large and small."

37 International Covenant on Civil and Political Rights arts. 3, 25, adopted Dec. 19, 1966, art. 3, 999 U.N.T.S. 171 [hereinafter ICCPR].

38 Convention on the Elimination of All Forms of Discrimination Against Women art. 7, Dec. 18, 1979, 1249 U.N.T.S. 13 [hereinafter CEDAW]. 
obligation to ensure participation of women. ${ }^{39}$

The absence or paucity of a significant proportion of the world's population from most international court benches suggests that something is awry. Why are women found in such meager numbers on most international court benches? Is a smaller pool of qualified women than men the reason? Who is selected for these positions, who is not, and why not? What does the paucity of women tell us about what values are driving the process of judicial selection on most international courts, and whether and how it may be flawed? Is outright discrimination against women the cause? Does a glass ceiling remain to be shattered in the international judiciary? Almost a quarter-century after Chinkin, Charlesworth and Wright wrote their seminal article, these questions deserve renewed attention and debate.

This is the first full-length journal article to attempt to tackle these questions. $^{40}$ It examines the relationship between selection procedures and sex representation on various international court benches. In so doing, it takes into account both quantitative and qualitative data on twelve different international courts, and it adopts a comparative approach to studying international courts. Although each of these courts operates within its own specific institutional and legal contexts, comparing their procedures and outcomes can result in insights into best and worst practices and what steps can be taken to strengthen these increasingly important institutions. The article exposes troubling qualities of selection procedures, which, if

39 The CEDAW Committee subsequently clarified that obligations extend "to all areas of public and political life" and are not limited to those spelled out in article 7. "It refers to the exercise of political power, in particular the exercise of legislative, judicial, executive and administrative powers. The term covers all aspects of public administration and the formulation and implementation of policy at the international, national, regional and local levels." U.N. Comm. on the Elimination of Discrimination Against Women, General Recommendation No. 23: Political and Public Life, $16^{\text {th }}$ Sess. 1997, at http://www.un.org/womenwatch/daw/cedaw/recommendations/recomm.htm \#recom22. CEDAW's article 8 states that "States Parties shall take all appropriate measures to ensure to women, on equal terms with men and without any discrimination, the opportunity to represent their Governments at the international level and to participate in the work of international organizations." CEDAW, supra note 38 , art. 8.

${ }^{40}$ But see, e.g., Jan Linehan, Women and Public International Litigation (Project on International Courts and Tribunals 2002), availabe at http://www.pict-pcti.org/publications/PICT_articles/ Women1.pdf (last visited January 19, 2015) (providing a brief introduction to the topic). 
remedied, may provide greater opportunities to others traditionally excluded from international court judgeships, as well as enhance the legitimacy credentials of these institutions. At the same time, it shows that trade-offs may exist between inclusion of women and other less traditional candidates, and states' desires to exert a high degree of control over international judicial selection procedures.

Part I provides statistics on sex representativeness on twelve global and regional international courts and establishes that women continue to serve on the vast majority of these institutions in paltry numbers. Part II seeks to explain whether and why glass ceilings continue to exist on most international courts. It argues that although women may make up a smaller percentage of elite lawyers, high level legal academics and diplomats than men, a smaller pool is an unsatisfying explanation for a number of reasons. Second, national nominations tend to be opaque and known only to a small group of insiders, making it difficult for potential candidates to be aware of and apply for positions at the national level. Third, where courts employ institutional screening mechanisms which interview, evaluate or rank candidates at the international level, women appear in greater numbers. Fourth, women tend to be present in higher numbers where constitutive instruments require or aspire to the inclusion of both male and female judges, as compared to when no such language is present.

Achieving sex representativeness requires the consideration and eventual implementation of reforms to judicial selection procedures. Part III proposes a number of possibilities for opening nomination procedures at the national level, including requiring states to publicize their procedures at the national level and the use of nominating commissions at the national or international levels. Ultimately, it argues that if measures aimed at opening and making more transparent selection procedures fail to make the bench more representative or if states reject them, states should consider aspirational language for the inclusion of both male and female judges, as well as temporary mandatory quotas to enhance sex representation on the bench.

\section{How Balanced ARE InTERnAtional CoURT BenCHES?}

Table 1 shows the percentage of women judges serving on twelve different international courts in mid-2015. These courts span a wide array of subject matters, from human rights to the Law of the Sea to international economic law to international criminal law, as well as many of the regions of the world. They include the African Court on Human and Peoples' Rights, the Andean Tribunal of Justice, the European Court of Human Rights, the European Court of Justice, the Court for the Economic 
Community of West African States (ECOWAS), the Inter-American Court of Human Rights, the International Criminal Court, the International Court of Justice, the International Criminal Tribunals for Rwanda and the Former Yugoslavia, the International Tribunal for the Law of the Sea, and the World Trade Organization's Appellate Body. The data are drawn from court websites or other relevant publications in mid-2015. ${ }^{41} \mathrm{Ad}$ hoc

41 Current Judges, European Court of Justice, available at http://curia.europa.eu/jcms/jcms/Jo2_7026/ (last visited June 1, 2015); Former Judges, European Court of Justice, available at http://curia.europa.eu/jcms/jcms/Jo2_9606/\#CJE (last visited June 1, 2015); Judges of the Court, African Court on Human and Peoples' Rights, available at http://www.african-court.org/en/index.php/about-thecourt/jurisdiction-3/judges (last visited June 1, 2015); Email from Ana Rita Ramirez of the Inter-American Court of Human Rights to author, concerning current and former judges (16 February 2015) (on file with author); Zaffaroni elected to inter-American rights court, Buenos Aires Herald.com, June 17, 2015, available at http://www.buenosairesherald.com/article/191791/zaffaroni-elected-tointeramerican-rights-court (last visited June 26, 2015); ECOWAS Court Holds Valedictory Court Session for Six Retiring Judges, ECOWAS Press Release (June 20, 2014), available at http://www.courtecowas.org/site2012/index.php?option=com_content\&vie $\mathrm{w}=$ article\&id=223:valedictorycourtsessionforsixretiringjudges\&catid=14:pr essrelease \&Itemid=36 (last visited June 26, 2015); The Past Members of the Court, ECOWAS (last visited June 26, 2015), available at http://www.courtecowas.org/site2012/index.php?option=com_content\&vie $\mathrm{w}=$ article\&id=29\&Itemid=32 (last visited June 26, 2015); The Judges of the Community Court of Justice, ECOWAS, available at http://www.courtecowas.org/site2012/index.php?option=com_content\&vie $\mathrm{w}=$ article\&id=260\&Itemid=31 http $/ / \mathrm{www}$. courtecowas.org/site2012/index. php?option $=$ com_content $\&$ view $=$ article $\&$ id $=260 \& I t e m i d=31$ (last visited June 26, 2015); Current Judges - Biographical Notes, International Criminal Court, available at http://www.icccpi.int/en_menus/icc/structure\%20of\%20the\%20court/chambers/the\%20jud ges/Pages/judges.aspx (last visited June 25, 2015); Former Judges, International Criminal Court, available at http://www.icccpi.int/EN_Menus/icc/structure $\% 20$ of $\% 20$ the $\% 20$ court/chambers/the $\% 20 j u$ dges/pages/former\%20judges.aspx (last visited June 25, 2015); Judges Continuing in Office to Complete Proceedings, International Criminal Court, available at http://www.icccpi.int/en_menus/icc/structure\%20of\%20the $\% 20$ court/chambers/the\%20jud 
investment or trade arbitral panels, such as those arising under the International Center for the Settlement of Investment Disputes or the World Trade Organization are not included. ${ }^{42}$

ges/Pages/judges $\% 20$ continuing $\% 20$ in $\% 20$ office $\% 20$ to $\% 20$ complete $\% 20 \mathrm{pr}$ oceedings.aspx (last visited June 25, 2015); Judges of the Court since 1959, European Court of Human Rights, available at http://www.echr.coe.int/Documents/List_judges_since_1959_ENG.pdf (last visited April 30, 2015); Appellate Body Members, World Trade Organization, available at https://www.wto.org/english/tratop_e/dispu_e/ab_members_descrp_e.htm (last visited June 25, 2015); All Members, International Court of Justice, available at http://www.icj-cij.org/court/index.php?p1=1\&p2=2\&p3=2 (last visited June 25, 2015); Libro Testimonio Comunitario, Tribunal Andino de Justicia (2004), available at http://www.tribunalandino.org.ec/sitetjca/index.php?option=com_filecabine $\underline{t \& v i e w=f i l e s \& i d=7 \& I t e m i d=35}$ (last visited June 26, 2015); Emails from Angie Sasaki of Andean Tribunal of Justice to author (Dec. 5, 2014, April 16, 2015, May 5, 2015) (on file with author); Members, International Tribunal of the Law of the Sea, available at https://www.itlos.org/thetribunal/members/ (last visited June 25, 2015); Members of the Tribunal since 1996, International Tribunal of the Law of the Sea, available at https://www.itlos.org/en/the-tribunal/members-of-the-tribunal-since-1996/ (last visited June 28, 2015); Annual Reports of the International Criminal Tribunal for Rwanda to the General Assembly and Security Council, 19962014; Chambers, United Nations International Criminal Tribunal for Rwanda, available at http://www.unictr.org/en/tribunal/chambers (last visited June 1, 2015); The Judges, ICTY, available at http://www.icty.org/sid/151 (last visited June 1, 2015); Former Judges, ICTY, available at http://www.icty.org/sid/10572 (last visited June 1, 2015). When one judge completed his or her tenure during the same year as another was elected, only the judge elected that year was counted for that year.

${ }^{42}$ In 2009 , only $9 \%$ of ICSID arbitrators were women and $17 \%$ of WTO panel members were women. See Grossman I, supra note 13, at 680. In 2007, Susan Franck found that only $3.5 \%$ of investment treaty arbitrators were women. Susan D. Franck, Empirically Evaluating Claims About Investment Treaty Arbitration, 86 N. C. L. REV. 1, 81 (2007). 
Table 1. Percentage Women Judges on Courts in Mid-2015

\begin{tabular}{|c|c|c|c|c|c|c|}
\hline Court & Af. Ct. HPR & ATJ & ECHR & $E C J$ & ECOWAS & IACHR \\
\hline $\begin{array}{l}\text { \% Women } \\
\text { (mid 2015) }\end{array}$ & $2 / 11=18 \%$ & $2 / 4=50 \%$ & $15 / 45=33 \%$ & $5 / 28=18 \%$ & $1 / 7=14 \%$ & $1 / 7=14 \%$ \\
\hline Nationality & $\begin{array}{l}\text { Nigeria, } \\
\text { Uganda }\end{array}$ & $\begin{array}{l}\text { Bolivia, } \\
\text { Colombia }\end{array}$ & $\begin{array}{l}\text { Austria, } \\
\text { Croatia, } \\
\text { Estonia, } \\
\text { Finland, } \\
\text { Georgia, } \\
\text { Germany, } \\
\text { Ireland, } \\
\text { Monaco, } \\
\text { Romania, } \\
\text { San Marino, } \\
\text { Sweden, } \\
\text { Switzerland, } \\
\text { FYR } \\
\text { Macedonia, } \\
\text { Turkey, } \\
\text { Ukraine }\end{array}$ & $\begin{array}{l}\text { Spain, } \\
\text { Romania, } \\
\text { Austria, } \\
\text { Netherlands, } \\
\text { Estonia }\end{array}$ & $\begin{array}{l}\text { Guineau } \\
\text { Bissau }\end{array}$ & Costa Rica \\
\hline Court & $I C C$ & ICJ & ICTR & $I C T Y$ & ITLOS & $W T O-A B$ \\
\hline \multirow[t]{3}{*}{$\begin{array}{l}\text { \% Women } \\
\text { (mid 2015) }\end{array}$} & $7 / 18=39 \%$ & $3 / 15=20 \%$ & $\begin{array}{l}\text { Permanent } \\
2 / 9=22 \%\end{array}$ & $\begin{array}{l}\text { Permanent } \\
2 / 19=11 \%\end{array}$ & $1 / 21=5 \%$ & $1 / 7=14 \%$ \\
\hline & & & $\begin{array}{l}\text { Ad Litem } \\
0 / 1=0 \%\end{array}$ & $\begin{array}{l}\text { Ad Litem } \\
1 / 3=33 \%\end{array}$ & & \\
\hline & & & $\begin{array}{l}\text { Total } \\
2 / 10=20 \%\end{array}$ & $\begin{array}{l}\text { Total } \\
3 / 22=14 \%\end{array}$ & & \\
\hline Nationality & $\begin{array}{l}\text { Japan, } \\
\text { Kenya, } \\
\text { Botswana, } \\
\text { Dominican } \\
\text { Republic, } \\
\text { Belgium, } \\
\text { Argentina, } \\
\text { Brazil }\end{array}$ & $\begin{array}{l}\text { China, } \\
\text { Uganda, } \\
\text { United } \\
\text { States }\end{array}$ & $\begin{array}{l}\text { Madagascar, } \\
\text { Pakistan }\end{array}$ & $\begin{array}{l}\text { Madagascar, } \\
\text { Pakistan }\end{array}$ & Argentina & China \\
\hline
\end{tabular}

Table 1 demonstrates that the smallest court in the group, the Andean Tribunal of Justice, was also the court with the highest percentage of women judges in mid-2015. Two of the four judges, or 50\%, were women. The next highest percentage of women served on the International Criminal Court, with 39\% percent women judges, or 7 female out of 18 total judges, and then the European Court of Human Rights, where women made up 33\% 
of the 45 judges on the court. On the nine remaining courts, men made up $80 \%$ or more of the total number of judges on the bench.

Table 1 also lists the countries of origin of women judges. Interestingly, the vast majority of the women on the global, rather than regional, courts came from outside of Western Europe and the United States. The women on the International Criminal Court were from Japan, Kenya, Botswana, Dominican Republic, Belgium, Argentina and Brazil. Only one of seven women on the ICC came from Western Europe. The women on the International Criminal Tribunal for the Former Yugoslavia and the International Criminal Tribunal for Rwanda's Appellate Chamber were from Pakistan and Madagascar. The lone women on the World Trade Organization Dispute Settlement Body's Appellate Body and on the International Tribunal for the Law of the Sea were Chinese and Argentinian, respectively. One of the three women on the ICJ, Joan Donoghue, haled from the United States, while the other two female judges were Chinese and Ugandan. While not all states are parties to all of the global courts, ${ }^{43}$ a significant number of Western European and North American states are parties to or participate in most of them.

Figures 1 through 12 show the percentage of women judges serving on these same twelve courts from their establishment through mid-2015. While on some courts, a discernable upwards trend exists in the percentage of women judges, on others the number of women appears to have stayed constant or relatively, or decreased. The data suggest that the percentage of women judges has generally increased over time on the Andean Tribunal of Justice, the European Court of Human Rights, and the International Court of Justice. On the other hand, the number of women has remained constant on the African Court on Human and Peoples' Rights and relatively constant on the International Tribunal for the Law of the Sea, since Elsa Kelly became the only woman to have served on the bench in 2011. The percentage of woman serving on the bench today is lower than in previous years on the Inter-American Court of Human Rights, ECOWAS, the ICTY and ICTR for both permanent and ad litem judges, the International Criminal Court, the WTO Appellate Body, the European Court of Human Rights, and the European Court of Justice.

43 The ICTY and the ICTR were created by Security Council resolutions, and therefore no state is formally a "party." S.C. Res. 827, U.N. Doc. S/RES/827 (May 25, 1993) (ICTY) [hereinafter ICTY Statute]; S.C. Res, 955, U.N. Doc. S/RES/955 (Nov. 8, 1994) (ICTR) [hereinafter ICTR Statute]. 

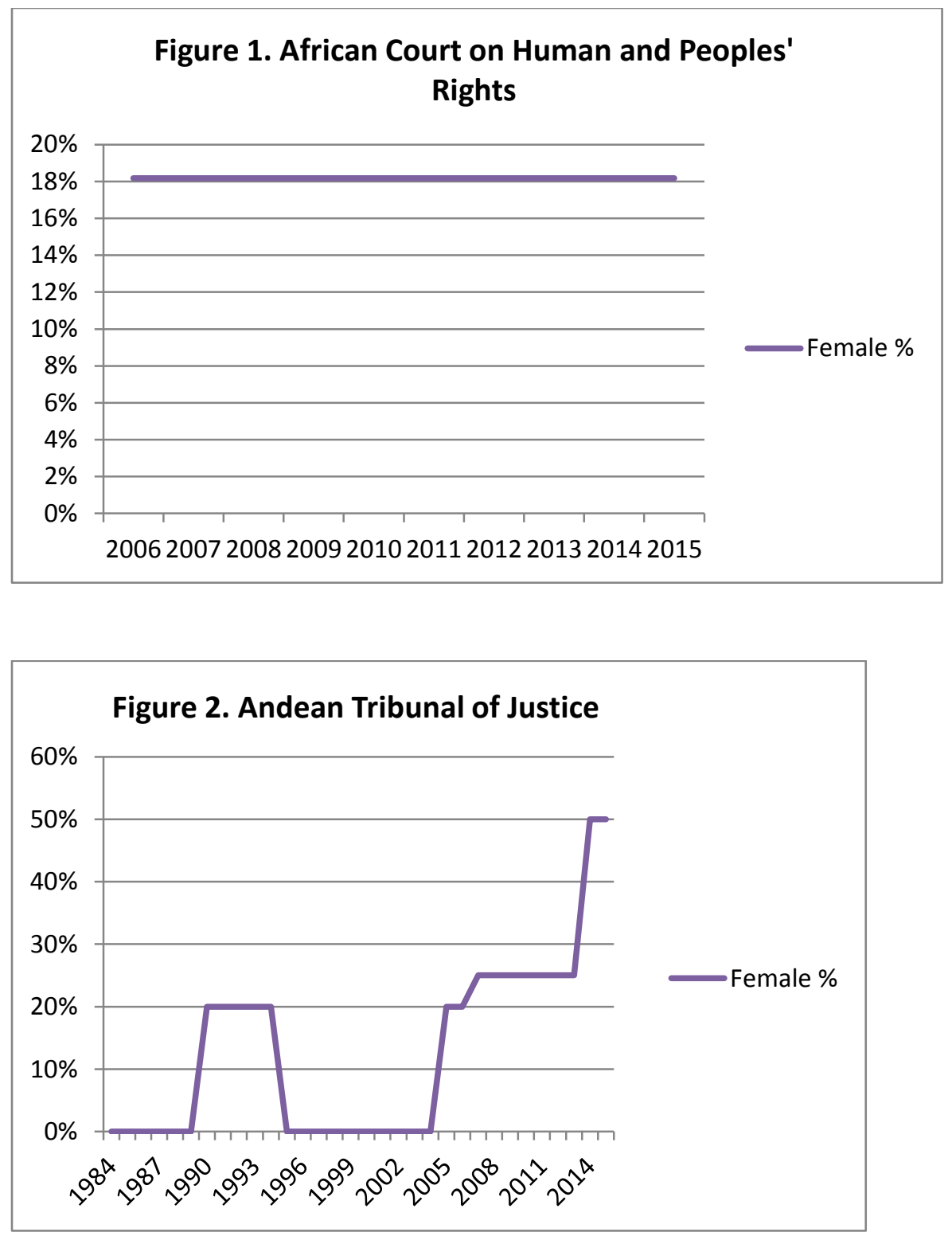

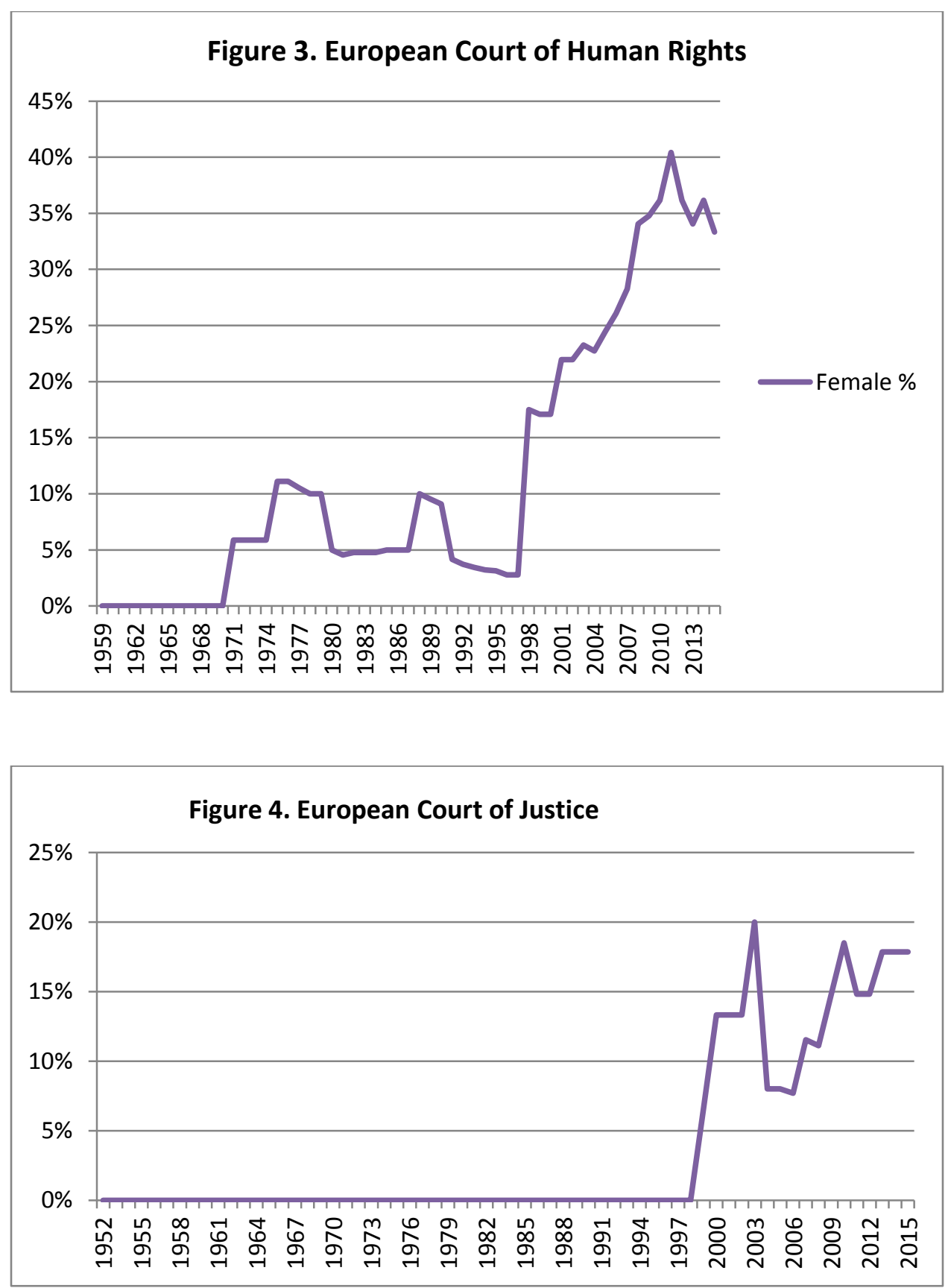

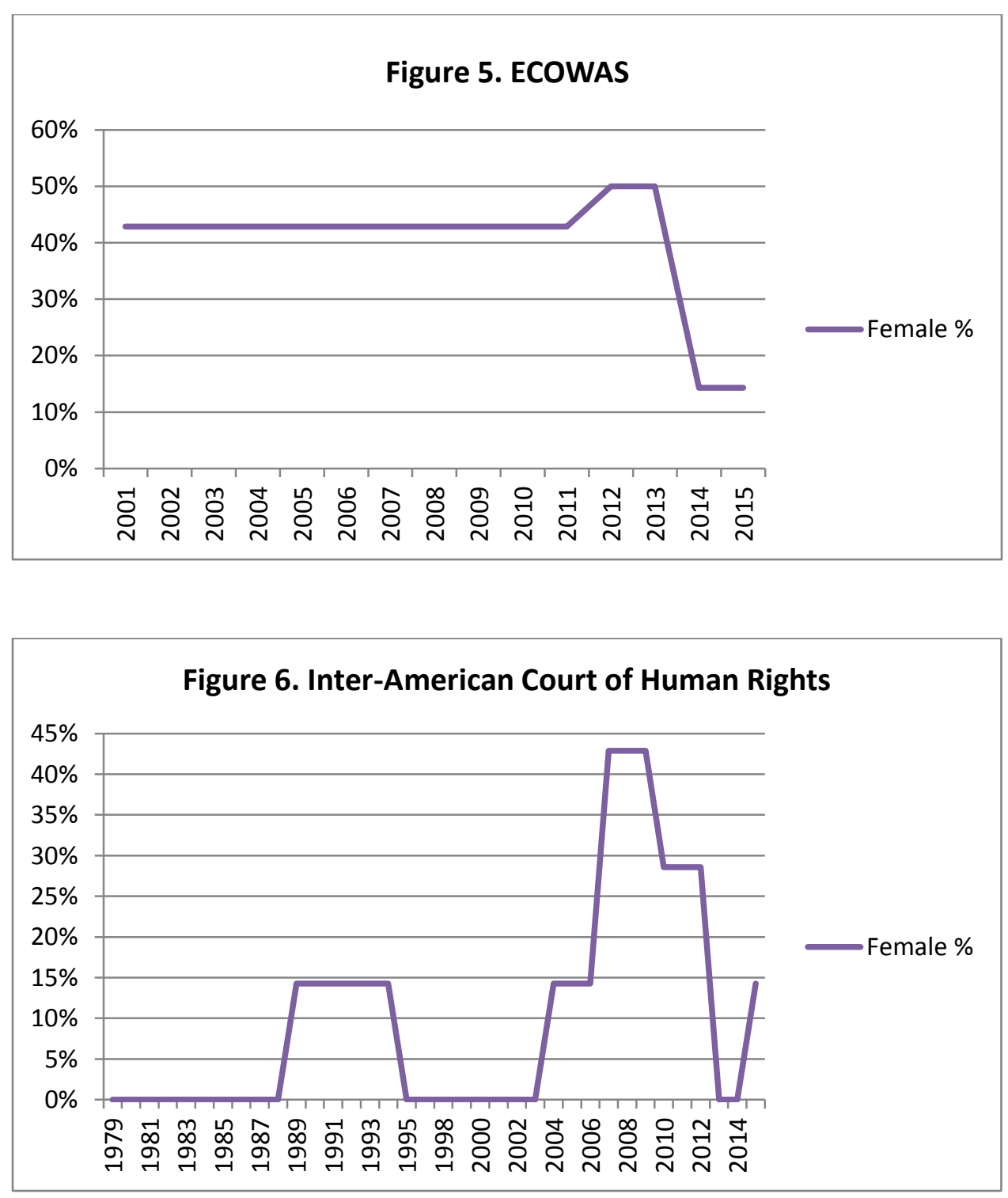

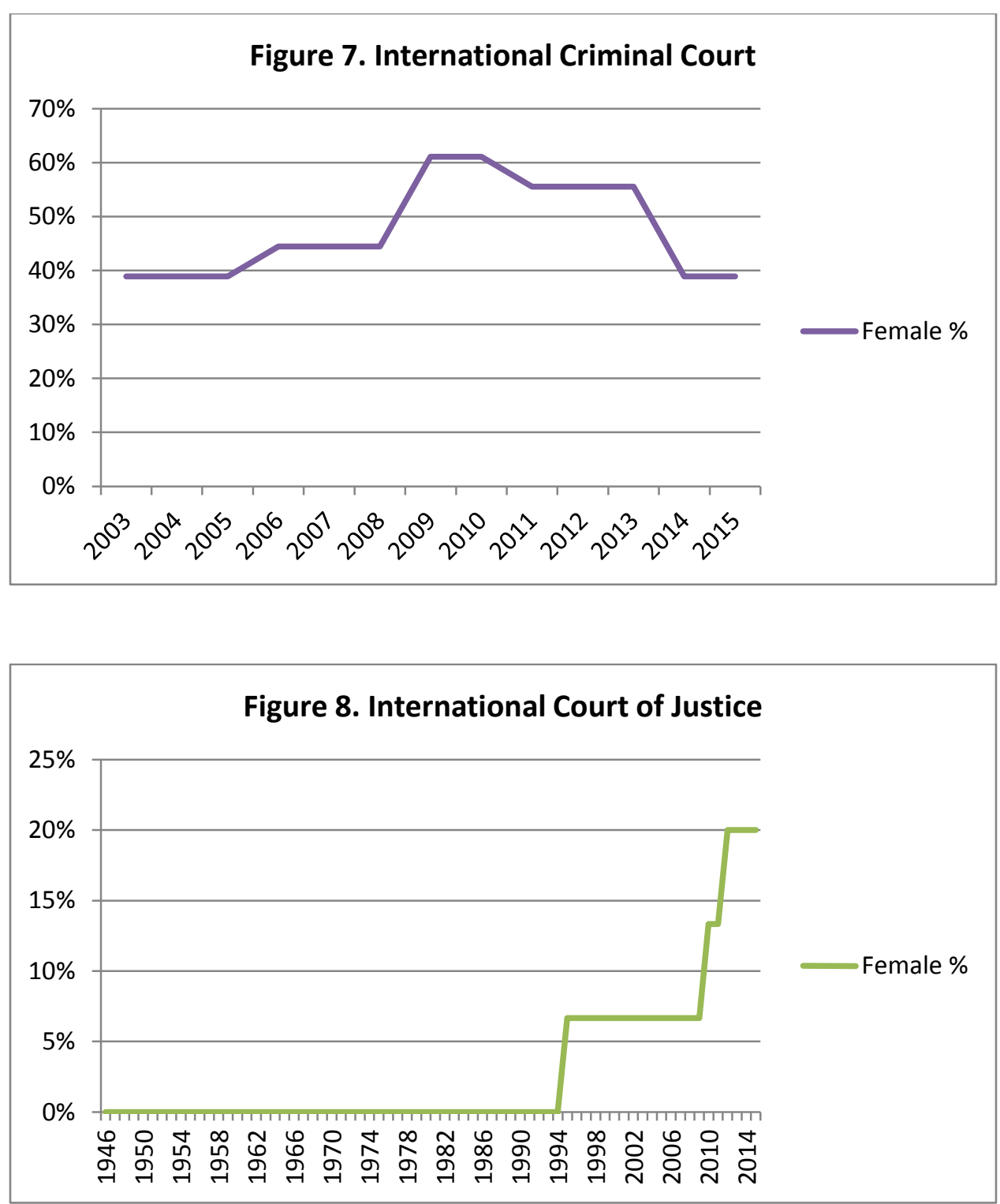

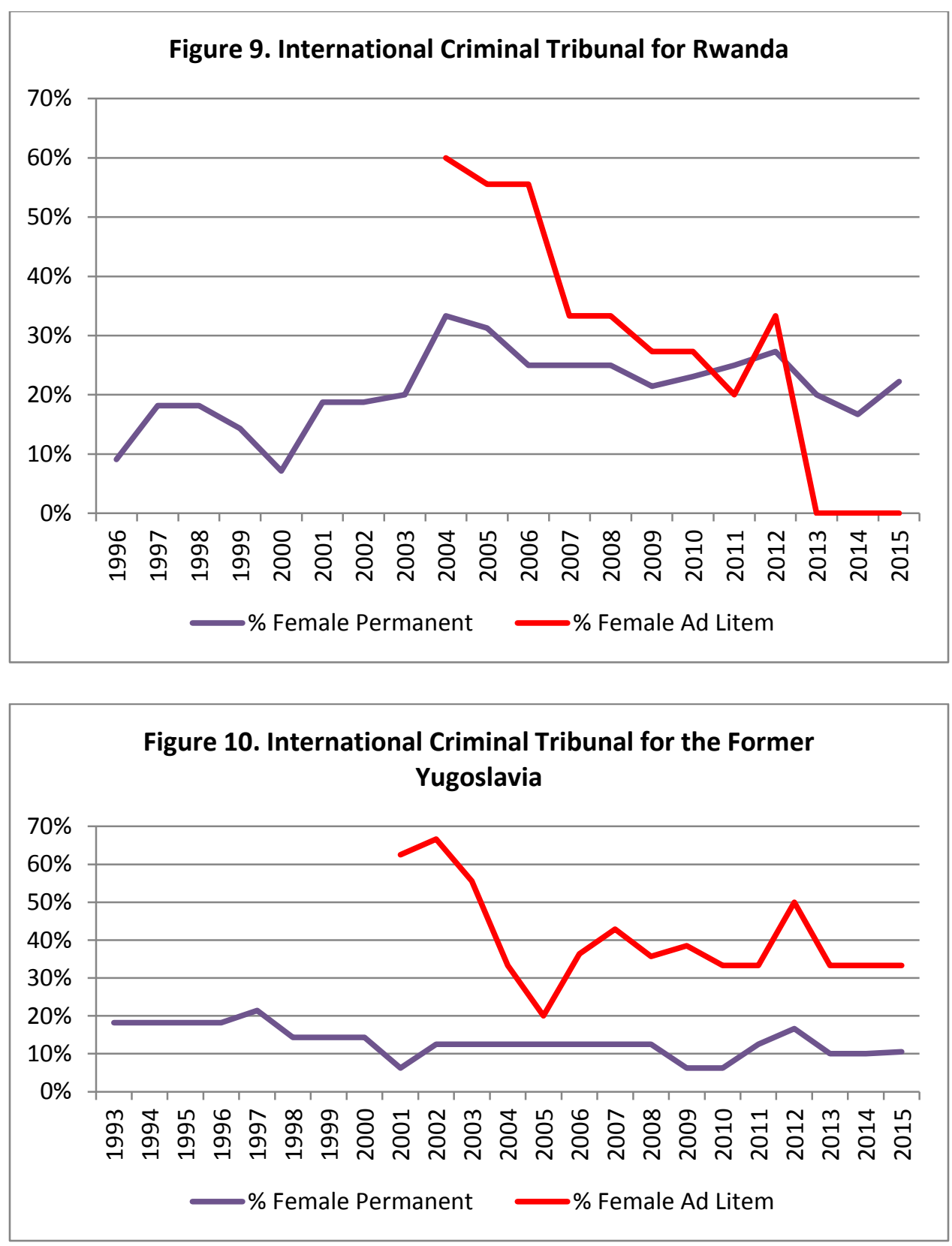


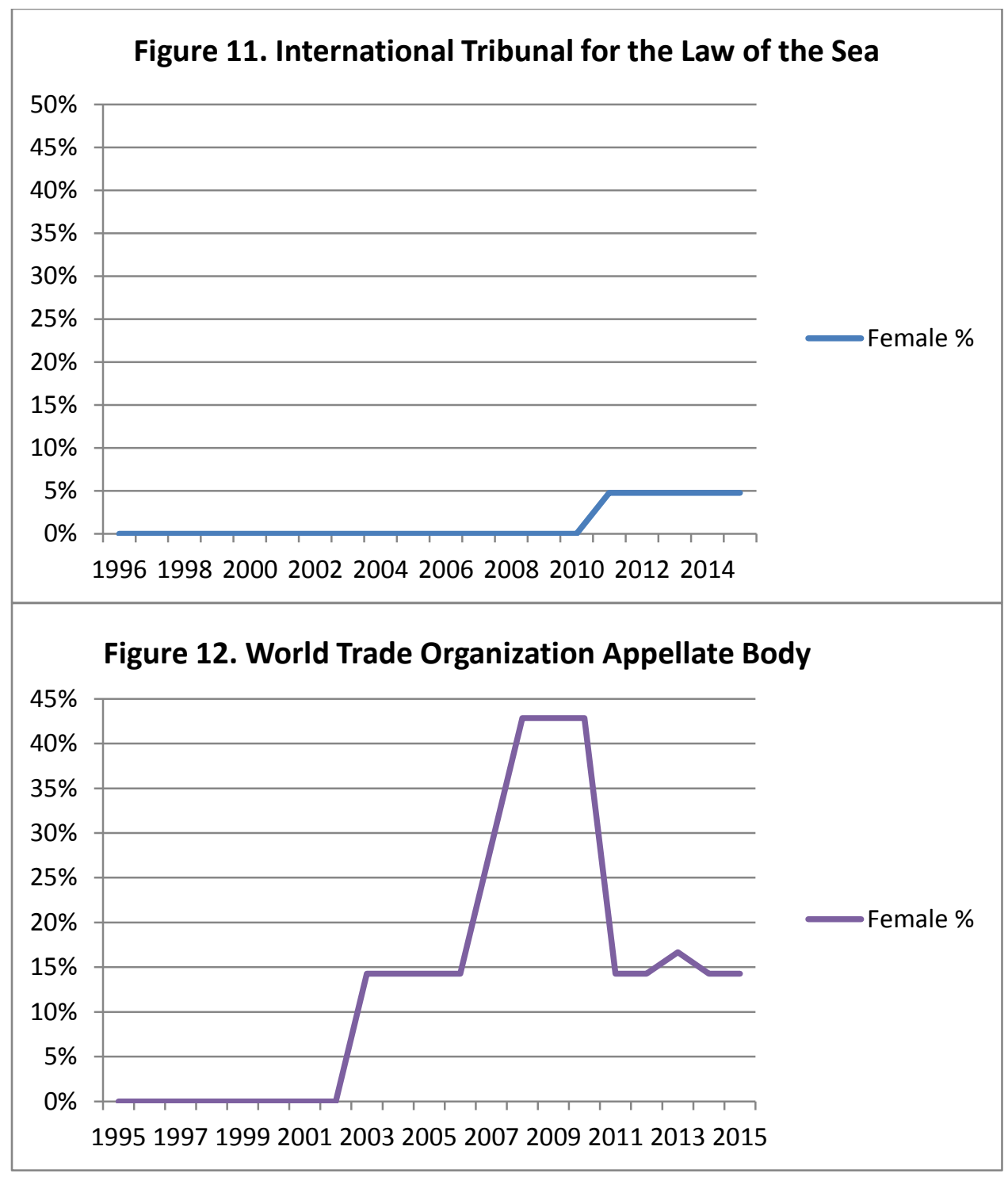

Figure 13 compares the percentage of women judges each year on all courts with representation requirements, either in the form of mandatory or virtually mandatory quotas - the ICC and the ECHR since 2004 - or aspirational language favoring balanced representation of the sexes - the ECHR from the late 1990s until 2003, the ICTY and ICTR with respect to ad litem judges only, and the African Court on Human and Peoples' Rights. The ECHR is included in the group of courts with representation requirements since establishment, even though its emphasis on balanced representation began only in the late 1990s. While the percentage of women judges has increased over time for both categories of courts, the overall percentage of women judges on courts with no representativeness 
requirement has never broken $20 \%$. It has reached $40 \%$ for courts with representativeness requirements.

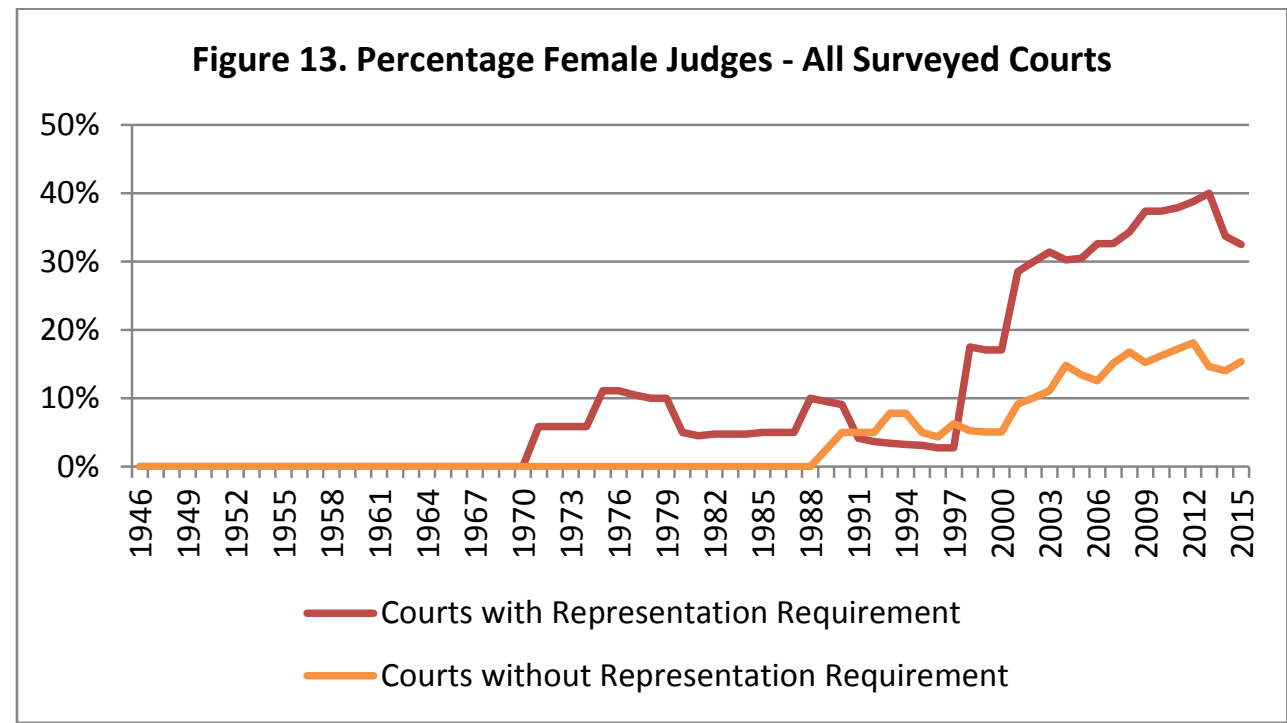

Figure 14 contains the percentage of slots allocated to women on each of the twelve courts since their establishment. The percentage was calculated by dividing the total number of women judges each year by the total number of male and female judges per year. The ICC is the Court that has had the most slots allocated to women since its establishment (47\%), followed by ad litem judges on the ICTY (41\%), and then ECOWAS $(40 \%)$. Women served in the lowest percentages on ITLOS $(2 \%)$, the ICJ (3\%), the ECJ (6\%), and the Inter-American Court of Human Rights (10\%). 


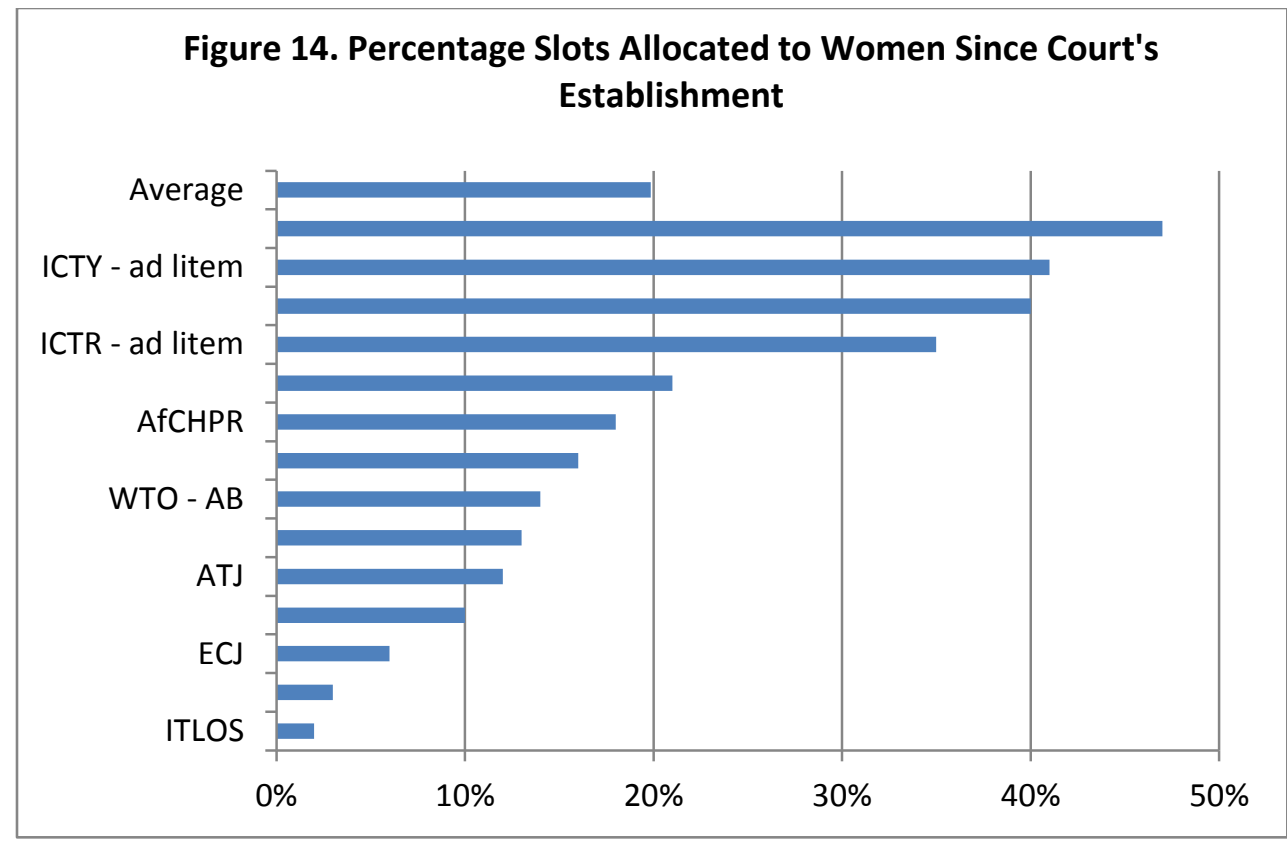

II. WHY SO FEW WOMEN?

Why are women under-represented and men over-represented on most international courts in comparison to their numbers in the world's population $?^{44}$ While a smaller pool of candidates appears to help explain the statistics to some extent, the argument lacks persuasive force when analyzed in light of the data on women's participation on international courts. A comparison of national nomination procedures and selection procedures at the international level suggests that courts with more open nomination procedures and institutional screening mechanisms may put more women on the bench. In addition, courts with mandatory or near mandatory sex representation requirements are more likely to have higher percentages of women on the bench. Finally, a lack of political will may account to some degree for the paucity of women on most international court benches, presenting a substantial hurdle to diversification of the international judiciary.

\section{A. The Limited Pool}

${ }^{44}$ A United Nations Study estimated that in 2010, there were 101.6 males per 100 females in the world. United Nations, Population Division, Statistics, available at http://esa.un.org/unpd/wpp/ExcelData/population.htm (last visited May 26, 2014). 
One possible explanation for the paucity of women judges on international courts is that they make up a much smaller percentage of the available pool of candidates than men do. Judges are usually selected from legal academia, the judiciary and the diplomatic corps in each country. ${ }^{45}$ Women are typically found in lower numbers than men in the legal profession generally, and in the highest echelons of the profession in most if not all countries. In many states, women make up a smaller proportion of lawyers. An exceptional example is Saudi Arabia, which only recently allowed women to become lawyers. ${ }^{46}$ According to a recent study by Ethan Michelson, 36\% of all countries have fewer than 30\% female lawyers, and $36 \%$ of the world's lawyers are women. ${ }^{47}$

While the number of women lawyers is high in some states, numbers alone do not paint an accurate picture of women's status in the legal profession globally or in each state. Women are frequently underrepresented at the highest levels of the profession. For example, while Michelson's study estimated that $48 \%$ of lawyers in the UK are female, women accounted for 35\% of practicing barristers and 11\% of Queen's Counsel in 2010. ${ }^{48}$ A similar dynamic exists in the South African courts. ${ }^{49}$ In 2003 , nearly $60 \%$ of law schools in the UK had never had a female professor and $83 \%$ of all law professors were men. ${ }^{50}$ A 2003 book examining women in the legal profession from a comparative perspective

${ }^{45}$ TERRIS, ROMANO \& SWIGART, supra note 10, at 20.

${ }^{46}$ Neil MacFarquhar, Saudi Monarch Grants Women Right to Vote, N.Y. Times, Sept. 25, 2011, at http://www.nytimes.com/2011/09/26/world/middleeast/women-to-vote-insaudi-arabia-king-says.html.

${ }^{47}$ Ethan Michelson, Women in the Legal Profession, 1970-2010: A Study of the Global Supply of Lawyers, 20 InD. J. Global Legal StUd. 1071, 1089, Table A6, 35 (2013). A sampling of estimates of the percentage of female lawyers is drawn from the study: $32 \%$ (USA), $5 \%$ (India), $66 \%$ (Brazil), 35\% (Mexico), 21\% (China), 48\% (UK), 45\% (Russia), 27\% (Indonesia), 26\% (Egypt), 50\% (France), 16\% (Japan). Id.

48 About the Bar: Statistics, The Bar Council, http://www.barcouncil.org.uk/about-the-bar/facts-andfigures/statistics/\#AllBarStats, (last visited March 23, 2014).

${ }^{49}$ Ruth B. Cowan, Women's Representation on the Courts in the Republic of South Africa, 6 U. MD. L.J. RACE, RELIGION, GENDER \& Class 291, s. C (2006).

${ }^{50}$ Celia Wells, The Remains of the Day: The Women Law Professors Project, in WOMEN IN THE WORLD's LEGAL PROFESSIONS 227(Ulrike Schultz \& Gisela Shaw, eds., 2003). 
found that women were underrepresented in the most lucrative sectors and highest echelons of the legal profession in most countries surveyed, including Canada, Australia, New Zealand, UK, Israel, Germany, Holland, Poland, France and Japan. ${ }^{51}$ Several studies reach the same conclusions in the United States. ${ }^{52}$

Although lower levels of the judiciary in many countries are increasingly feminized, men continue to be overrepresented in most countries, especially at intermediate and highest court levels. ${ }^{53}$ In 2010, women generally made up $0 \%, 8 \%, 18 \%, 25 \%, 33 \%$, and $35 \%$ of the higher courts of Paraguay, Guatemala, Brazil, Chile, El Salvador and Costa Rica's

${ }^{51}$ Fiona M. Kay \& Joan Brockman, Barriers to Gender Equality in the Canadian Legal Establishment, in WOMEN IN THE WORLD's LEGAL PROFESSIONS, supra n. 50, at 60; Rosemary Hunter, Women in the Legal Profession: The Australian Profile, in WOMEN IN THE WORLD's LEGAL PROFESSIONS, supra n. 50, at 89; Georgina Murray, New Zealand Women Lawyers at the End of the Twentieth Century, in WOMEN IN THE WORLD's LEGAL PROFESSIONS, supra n. 50, at 128-29; Clare M.S. McGlynn, The Status of Women Lawyers in the United Kingdom, in WOMEN IN THE WORLD's LEGAL PROFESSIONS, supra n. 50, at 139; see Bryna Bogoch, Gender, Trials and Professional Performance in Israel, in WOMEN IN THE WORLD's LEGAL PROFESSIONS, supra n. 50, at 251 (While “occupational segregation" exists in Israel, women "have reached the peak of the profession in the public sphere."); Ulrike Schultz, The Status of Women Lawyers in Germany, in WOMEN IN THE WORLD's LEGAL PROFESSIONS, supra $\mathrm{n}$. 50, at 285, 278-9 (pointing out that less than $6 \%$ of law professors in Germany were women in 2003); Leny E. de Groot- van Leuwen, Women in the Dutch Legal Profession (1950-2000), in WOMEN IN THE WORLD's LEGAL PROFESSIONS, supra n. 50, at 343, 354; Malgorzata Fuszara, Women Lawyers in Poland under Impact of Post-1989 Transformation, in WOMEN IN THE WORLD's LEGAL PROFESSIONS, supra n. 50, at 375-6, 383; see also Anne Boigeol, Male Strategies in the Face of the Feminisation of a Profession, in WOMEN IN THE WORLD'S LEGAL PROFESSIONS, supra n. 50, at 405, 412-13; Yuriko Kaminaga \& Jorn Westhoff, Women Lawyers in Japan: Contradictory Factors in Status, in WOMEN IN THE WORLD's LEGAL PROFESSIONS, supra n. 50, at 480-1.

52 See, e.g., Steven A. Boutcher \& Carole Silver, Gender and Global Lawyering: Where are the Women?, 20 IND. J. GLOBAL LEGAL STUD. 8, (2003), available at http://ssrn.com/abstract=2258221.

${ }^{53}$ See, e.g., Maritza Formisano \& Valentine M. Moghadam, Women in the Judiciary in Latin America: An Overview of Progress and Gaps, UNESCO (2005), 4, 20 (discussing Latin America). 
higher courts, respectively. ${ }^{54}$ Similarly, while women are present in high numbers at the lowest levels of the judiciary in the Netherlands, France, Spain and Italy, it takes them longer to be promoted and they are present in low numbers at the highest levels of the judicial hierarchy. ${ }^{55}$ According to the Organisation for Economic Co-operation and Development (OECD), in 2012, 49.2\% of professional judges in OECD countries were women, but only $29.4 \%$ of court presidents and $26 \%$ of Supreme Court justices were women. ${ }^{56}$ In April 2011, according to the UN Progress of the World's Women 2011-2012 Report, women made up 67\% of the judges on the highest courts of Serbia and 50\% in Rwanda, but no women judges were present on the highest courts of Andorra, Cameroon, Cape Verde, Hungary, Malaysia, Pakistan and Peru. ${ }^{57}$ Overall, for 65 of 78 states surveyed for the UN report, women made up $33 \%$ or less of the bench. ${ }^{58}$

Studies have identified numerous causes for the lower percentage of female lawyers at the highest levels of the legal profession at the domestic level, including the inflexible structure of specific work environments such as large private law firms, shouldering a disproportionate burden of domestic responsibilities, opting out to care for family due to familyunfriendly policies, preferring increased flexibility and discrimination. ${ }^{59}$ To the extent that glass ceilings or discrimination keep women at lower levels of the judiciary in the domestic context, the available pool will look smaller than it is.

The extent to which women are present (or absent) at the bars of international courts may also have an impact on the diversity of the bench.

${ }^{54}$ Sital Kalantry, Women in Robes, AMERICA's Q. 83, 84 Table I (Summer 2012) (citing Economic Commission for Latin America statistics from 1998-2010), http://www.lwv.org/files/Women\%20in\%20RobesSital\%20Kalantry.pdf (last visited May 22, 2014).

${ }^{55}$ Justice Susan Glazebrook, Talk delivered to Chapman-Tripp Women and Law Event, Looking through the Glass: Gender Inequality at the Senior Levels of New Zealand's Legal Profession 3 (2010).

56 OECD, Gender Equality, Women in Government, available at http://www.oecd.org/gender/data/womeningovernment.htm (last visited June 25, 2015).

${ }^{57}$ UN Women, 2011- 2012 Progress of the World's Women Figure 2.6 (New York: UN Women, 2011).

${ }^{58} I d$.

${ }^{59}$ See, e.g., generally, Leah V. Durant, Gender Bias and the Legal Profession: A Discussion of Why There Are Still So Few Women on the Bench, 4 Margins: Md. L.J. Race, Religion, Gender \& Class 181 (2004); Boutcher \& Silver, supra note [[]], at 9. 
For example, women are present in meager numbers as oral advocates at the International Court of Justice. In the 33 contentious cases argued in the ICJ between 1999 and 2012, women made up only 11\% of lawyers arguing before the Court, and their arguments made up only $7.44 \%$ of the total speaking time. ${ }^{60}$ Only four female lawyers appeared before the ICJ more than once in the entire 13 year period, while 59 men appeared more than once during the same period, and these four female lawyers accounted for only $2.9 \%$ of the speaking time. ${ }^{61}$ There are calls for increased diversity among counsel before the International Criminal Court as well. ${ }^{62}$ Even if the career path of an international judge does not necessarily include serving as a litigator before it, the lack of diversity on the bench and at the bar may contribute to a culture of complacency. It is normal to see few women in these contexts. The lack or paucity of women may make the problem itself invisible or appear inevitable. ${ }^{63}$

It is difficult to quantify the pool of women available from the diplomatic corps due to a lack of systematic comparative data. Nonetheless, in many OECD countries, women tend to be found in higher numbers in the public sector than in the private sector; they made up $57 \%$ of public sector employees in OECD countries in 2010. ${ }^{64}$ Women held $40 \%$ of middle management positions and $29 \%$ of top management positions in government in 2010. ${ }^{65}$ According to United Nations statistics, women made up an average of $29 \%$ of legislators, senior officials, and managers in the world. ${ }^{66}$ Yet, in 2012, only 11 out of 115 European Union Ambassadors

${ }^{60}$ Kumar \& Rose, supra note 8, at 904.

${ }^{61} \mathrm{Id}$.

${ }^{62}$ ICC-ASP/12/Res.8, § 33 (27 Nov. 2013), available at http://www.icccpi.int/iccdocs/asp_docs/Resolutions/ASP12/ICC-ASP-12-Res8-ENG.pdf.

${ }^{63}$ See Cowan, supra note 49, at s. D (explaining that women judges in South Africa stress the need for greater visibility of women on the South African bench, "so that women in judicial robes can become part of the cultural consciousness...").

${ }^{64}$ OECD, Gender Equality, Women in Government, available at http://www.oecd.org/gender/data/womeningovernment.htm (last visited June 25, 2015).

${ }^{65} \mathrm{Id}$.

${ }^{66}$ See Statistics and Indicators on Women and Men, Women's Share of Legislators, Senior Officials and Managers, United Nations Statistics Division, available at http://unstats.un.org/unsd/demographic/products/indwm/default.htm (last visited June 25, 2015). 
were women. ${ }^{67}$

The limited pool argument lacks persuasive force for a number of reasons. First, in a world where women serve as presidents, ambassadors, judges, and professors, it is difficult to believe that only one woman in North, South or Central America or the Caribbean is qualified to sit on the Inter-American Court of Human Rights, only one woman in the Economic Community of West Africa can meet the requirements of its court, and that only one woman in a world of over 7 billion people is qualified to sit on the Law of the Sea Tribunal or the World Trade Organization's Appellate Body. In other words, a very small pool is still sufficient to fill a handful of open seats on international courts. Second, the limited pool argument is unconvincing where women are present in higher numbers for a period and then drop off substantially. The ECOWAS Court, the WTO Appellate Body, and the Inter-American Court of Human Rights had three women on their seven-member benches just a few years ago, but they only had one each by mid-2015. The percentage of women judges has also dropped dramatically over time on both the ICTY and the ICTR. It is reasonable to assume that the female pool of qualified candidates would grow over time, not shrink.

In addition, the limited pool argument fails to explain why some global courts with very similar qualifications requirements and subject matter jurisdictions exhibit stark differences in the percentages of female judges. In mid-2015, women made up $39 \%$ of judges on the ICC, but only $11 \%$ and $22 \%$ of permanent judges on the ICTY and the ICTR. Presumably, ICC judges should have similar qualifications to those on the ICTY or ICTR, since all of them address international criminal law matters. In the same vein, a limited pool cannot explain why so many more women have served as ad litem judges on the ICTY than permanent judges, or why the number of women ad litem judges on the ICTR dropped from a high of $60 \%$ in 2004 to a low of $20 \%$ in $2011 .^{68}$

${ }^{67}$ See, e.g., Talyn Rahman-Figueroa, Celebrating the Rise of Women in Diplomacy, Diplomatic Courier: A Global Affairs Magazine, March 8, 2012, available at http://www.diplomaticourier.com/news/topics/diplomacy/1374-celebrating-the-rise-ofwomen-in-diplomacy (noting that only 11 female ambassadors served as Permanent Representatives of their states to the United Nations in 2002 and discussing the challenges to women in the United Kingdom's diplomatic corps); Ann Wright, For the Record: Breaking through Diplomacy's Glass Ceiling, ForeIGN SERviCE JOURNAL 55-56 (October 2005), available http://afsa.org/sites/default/files/flipping_book/1005/files/assets/downloads/publication.pdf (noting that rapid progress was made starting with the Carter Administration in promoting women to chief-of-mission positions and other high level appointments, and that in 2003 only $25 \%$ of senior foreign service officers were women).

${ }^{68}$ See supra Figures 9 and 10. Ad litem judges were first elected to the 
Furthermore, the limited pool is unconvincing because it assumes that selection procedures aim to promote the most meritorious candidates in the first place. This is far from obvious. For example, in preparation for 2015 elections to the Inter-American Court of Human Rights, the Open Society Justice Initiative established a panel of experts to evaluate candidates nominated by states. The panel expressed concerns about whether one of the five candidates, Patricio Pazmiño Freire, would "be in a position to avoid conflicts of interest or to maintain the necessary independence and impartiality with regard to the Ecuadorian executive branch." ${ }^{69}$ The panel noted that he was appointed to Ecuador's Constitutional Court after the entire body was dissolved, which a 2013 Inter-American Court decision determined violated due process norms by arbitrary termination and impeachment proceedings against the previous judges. $^{70} \mathrm{He}$ was elected to the bench nonetheless. On the other hand, another judge, with a "long and deep commitment to human rights" lost his re-election bid. ${ }^{71}$ While this could arguably constitute an exceptional case, as discussed in more detail with reference to national nomination and international elections procedures, several scholars of international courts have argued that selection processes for international courts often have more to do with "political factors, rather than the individual selection criteria..." 72 In the same vein, Philippe Sands and Cherie Booth wrote: "in many states, nominations are handed out to reward political loyalty rather than legal excellence." 73 If so, the limited pool argument loses much of its purported explanatory force.

The limited pool argument is also problematic because it appears that the percentage of women on the bench does not necessarily correspond with the percentage of women lawyers a state may have. In other words,

ICTR in 2004. There were ten ad litem judges on the bench in 2011. After 2011, the number of ad litem judges was reduced to 3 and then to 1, as the tribunal sought to complete its work.

${ }^{69}$ Final Report of the Independent Panel for the Election of InterAmerican Commissioners and Judges (2 June 2015), 25-26, available at http://www.opensocietyfoundations.org/sites/default/files/iachr-panelreport-eng-20150603.pdf (last visited June 24, 2015) [hereinafter Independent Panel Report].

${ }^{70} I d$. at 26.

${ }^{71} I d$. at 29 .

${ }^{72}$ See, e.g., Selecting International Judges, supra note 20, at 95; see infra at note 302.

${ }^{73}$ Cherie Booth \& Philippe Sands, Keep Politics out of the Global Courts, The Guardian (July 13, 2001). 
growing the pool does not necessarily translate to more women on the bench. Although Michelson estimates that $50 \%$ of France's lawyers are women, ${ }^{74}$ no French woman has ever served as a permanent judge on the European Court of Justice, the European Court of Human Rights, the International Criminal Court, the International Court of Justice, the International Tribunal for the Law of the Sea, the ICTR or the ICTY, although French men have served on all of them. Michele Picard is the only French woman to have served on any of the international courts surveyed, as an ad litem judge on the ICTY. In the same vein, although women account for about $48 \%$ of the United Kingdom's lawyers according to Michelson, ${ }^{75}$ no British woman has ever served on the European Court of Justice, the International Criminal Court, the European Court of Human Rights, or the ICTY, although British men have. Dame Rosalynn Higgins, the first woman ever to serve as a permanent judge on the International Court of Justice is British, however. On the other hand, China, which is estimated to have about $21 \%$ female lawyers, ${ }^{76}$ has appointed women to the International Court of Justice and the World Trade Organization's Appellate Body; Chinese men have served on the ICJ, the ICTY and the ICTR. Russia has appointed no women to the European Court of Human Rights, the International Court of Justice, the International Tribunal for the Law of the Sea, the ICTR and ICTY, although Russian men have served there. Michelson estimates that $45 \%$ of Russia's lawyers are women. ${ }^{77}$ Only $16 \%$ of lawyers are women in Japan, ${ }^{78}$ yet Japanese women have served on both the ICTY and the ICC.

\section{B. There's an opening? The opacity of national nomination procedures}

The number of women serving as international court judges in proportion to their availability in the pool of qualified candidates raises serious questions about the definition of the pool itself and what procedures are utilized to identify candidates for the pool. This process generally takes place at the national level. National nominations practices can be grouped into three categories: (1) little to no guidance or transparency, (2) a high level of guidance or transparency, and (3) no nominations procedure at the national level. Most of the twelve courts surveyed fall into the first group, while the ECHR and the ECJ fall into the second, and ECOWAS into the third. A comparison of these three groups' selection procedures and

\footnotetext{
${ }^{74}$ Michelson, supra note 47, at A6, 35.

${ }^{75} \mathrm{Id}$.

${ }^{76} \mathrm{Id}$.

${ }^{77} \mathrm{Id}$.

${ }^{78} I d$.
} 
statistics on women's participation does not appear to yield concrete conclusions about the relationship between the amount of guidance provided or the degree of transparency in national nominations procedures, and the percentage of women judges on the bench in mid-2015 or historically. What is clear, however, is that national nomination procedures are frequently opaque and known only to well-connected insiders. Such procedures not only make it more difficult for outsiders to make it to the international election stage, but also, they raise questions about whether selection procedures aim to seat the most meritorious candidates in the first place.

\section{Group 1: Little Guidance or Transparency}

The ICJ, ICC, AfCHPR, ICTY, ICTR, WTO, ATJ, ITLOS, and IACHR contain the least guidance on national selection procedures. The ICJ Statute provides that a national group composed of up to four individuals named by states parties to the Permanent Court of Arbitration are charged with nominating candidates for the ICJ, and that the national group "is recommended to consult its highest court of justice, its legal faculties and schools of law, and its national academies and national sections of international academies devoted to the study of law."79 Interviews of individuals involved in selection, however, showed that few actually engage in the recommended consultation. ${ }^{80}$ National groups may nominate no more than four candidates and not more than two of them may be of the nationality of the national group; the number of candidates nominated by a group cannot be greater than double the number of seats to be filled. ${ }^{81}$ There are no separate guidelines or best practices available to states concerning domestic nominations procedures. In mid-2015, women made up $20 \%$ of the fifteen-member bench, but women account for only $3 \%$ of the court's slots since establishment. Dame Rosalynn Higgins (United Kingdom) became the first woman to serve as a judge on the ICJ in 1995. Xue Hanquin (China) and Joan Donoghue (United States) joined the bench in 2010, followed by Julia Sebutinde (Uganda) in 2012.

The Rome Statute of the ICC specifies that any state party may nominate a candidate for election, and the procedure for nomination should be the same as for the highest judicial offices of that State or by the same procedure utilized for the International Court of Justice. ${ }^{82}$ Nominations

${ }^{79}$ Statute of the International Court of Justice arts. 4-10, 26 June 1945, 59 Stat. 1055 (1945), TS No. 993 [hereinafter ICJ Statute].

${ }^{80}$ SELECTING INTERNATIONAL JUDGES, supra note 20, at 142-43.

${ }^{81}$ ICJ Statute, supra note 79, art. 5(2).

${ }^{82}$ Rome Statute of the International Criminal Court art. 36(4), 17 July 
must include a statement describing the candidate's competence in criminal law and procedure or relevant international law areas, and their language capabilities. ${ }^{83}$ Once the Secretariat receives the nominations, it must place them and any accompanying information on the ICC website as soon as possible. ${ }^{84}$ While the drafters of the Rome Statute and the Assembly of States Parties developed detailed rules concerning international elections procedures, discussed in the section below, the same does not appear to apply to national nominations. The Assembly of State Parties has encouraged states "to conduct thorough and transparent processes to identify the best candidates," but it has not issued guidelines as to what procedures would be appropriate. $^{85}$

During its $10^{\text {th }}$ Session (2011-2012), the Assembly of State Parties agreed on the creation of an Advisory Committee on Nominations. ${ }^{86}$ Despite its name, however, the Advisory Committee on Nominations plays no role whatsoever in the nomination process. Rather, it evaluates whether nominees already proposed by states meet the requirements of the Rome Statute, and is discussed further below. ${ }^{87}$ Scholars of the ICC and the Assembly of State Parties have expressed concerns that individual state nomination processes lack transparency and may not be driven by merit. ${ }^{88}$

1998, 2187 U.N.T.S. 90 [hereinafter Rome Statute].

${ }^{83} \mathrm{Id}$.

${ }^{84}$ ICC-ASP, Sixth Session, Res. ICC-ASP/3/Res.6, para. 8 (Sept. 10, 2004) [hereinafter Procedure for nomination to ICC].

${ }^{85}$ Strengthening the International Criminal Court and the Assembly of States Parties, ICC-ASP12/Res.8 (Advance copy) para. 27 (Nov. 27, 2013), available at http://www.icccpi.int/iccdocs/asp_docs/Resolutions/ASP12/ICC-ASP-12-Res8-ENG.pdf [hereinafter Strengthening the ICC].

${ }^{86}$ Res. ICC-ASP-10-Res.5-ENG, paras. 19-20 (Dec. 21, 2011). In the same resolution, the Assembly of the State Parties encouraged States Parties "to conduct thorough and transparent processes to identify the best candidates" for judgeships. Id.

${ }^{87}$ Report of the Bureau on the Establishment of an Advisory Committee on Nominations of judges of the International Criminal Court, Tenth Session, U.N. Doc. ICC/ASP/10/36 (Dec. 21, 2011).

${ }^{88}$ Strengthening the ICC, supra note 85, para. 27 ("Emphasizes the importance of nominating and electing the most highly qualified judges in accordance with article 36 of the Rome Statute, and for this purpose encourages States Parties to conduct thorough and transparent processes to identify the best candidates;"); SELECTING InTERNATIONAL JUDGES, supra note 20 . 
$39 \%$ of the judges on the ICC bench in mid-2015 were women. Women accounted for $47 \%$ of judicial slots since its establishment.

States parties to the constitutive instrument of the African Court on Human and Peoples' rights may nominate up to three candidates each for that court, two of whom must be nationals of that state and none of whom may share the nationality of any sitting member of the court. ${ }^{89}$ The Protocol establishing the Court provides that "[d]ue consideration shall be given to adequate gender representation in the nomination process," but provides no further guidance on national nominations. ${ }^{90}$ Interestingly, the African Union Commission, in correspondence to states in advance of elections taking place in June 2014, asserted that it was "mandatory" that states propose at least one female candidate each, given the low numbers of women on the bench. ${ }^{91}$ Also, the Commission suggested that in their nominations procedures, states should consider taking into account,

additional factors submitted to the AU Commission by Civil Society organizations: a) The procedure for nomination of candidates should be at the minimum that for appointment to the highest judicial office in the State Party; b) States Parties should encourage the participation of civil society, including Judicial and other State bodies, bar associations, academic and human rights organizations and women's groups, in the process of selection of nominees; c) State Parties should employ a transparent and impartial national selection procedure in order to create public trust in the integrity of the nomination process. ${ }^{92}$

In July 2014, one man was re-elected, and two men and one woman

${ }^{89}$ Protocol to African Charter on Human and Peoples' Rights on the Establishment of an African Court on Human and Peoples' Rights arts. 11(2) and 12, June 10, 1998, Doc. OAU/LEG/EXP/AFCHPR/PROT (III) (entered into force Jan. 25, 2004) [hereinafter Protocol to African Charter].

${ }^{90}$ Protocol to African Charter, supra note 89, art. 12.

${ }^{91}$ See Letter to Ministries of Foreign Affairs/External Relations of all Member States from the African Union Commission, Reference: BC/OLC/66.5/2954.14, available at http://legal.au.int/en/sites/default/files/2954.14_Bc-olc-66.5_Eng_0.pdf.

92 Letter to Ministries of Foreign Affairs/External Relations of all Member States from the African Union Commission, Reference: BC/OLC/66.5/2954.14, available at http://legal.au.int/en/sites/default/files/2954.14_Bc-olc-66.5_Eng_0.pdf. 
were elected to replace two men and one woman. ${ }^{93}$ In mid-2015, women made up $18 \%$ of the bench, a number which has remained constant since its establishment.

The Resolutions establishing the ICTY and ICTR provide almost no guidance on national nominations procedures. United Nations member states and non-member states maintaining permanent observer missions at the United Nations may nominate up to two candidates for permanent and four candidates for ad litem judges to the International Criminal Tribunals for the Former Yugoslavia and Rwanda, who meet the qualifications requirements and are not of the same nationality as each other or as a sitting member of the other tribunal or the appeals chamber. ${ }^{94}$ While for the nomination of ad litem judges, states are encouraged to take "into account the importance of a fair representation of female and male candidates," 95 no such requirement exists for permanent judges. No other guidance is provided as to national nominations. $11 \%$ of the permanent judges on the ICTY were women, while $22 \%$ of the permanent judges on the ICTR were women in mid-2015. The sole ad litem judge remaining on the ICTR was a man, while one of three ad litem judges on the ICTY was a woman. Women have served in $21 \%$ and $13 \%$ of the permanent judge slots on the ICTR and the ICTY, respectively, and $35 \%$ and $41 \%$ of the ad litem slots, respectively.

The constitutive instruments and rules of procedure (when relevant) of ITLOS, IACHR, and ATJ say nothing about suggested or required procedures for national nominations, beyond specifying qualifications for judges and nationality requirements. ${ }^{96}$ For example, the Statute of the Inter-

\section{${ }^{93}$ African Court on Human and Peoples' Rights, New Judges Appointed to the Court, available at http://www.african- court.org/en/index.php/news/latest-news/545-new-judges-appointed-to-the- court (last visited November 21, 2014). \\ 94 S. C. Res. 1329, Annex I art. 13, 13bis, UN Doc S/RES/1329 (2000);} S. C. Res. 143,1 Annex I, art. 12, 12bis, UN Doc S/RES/1431 (2002). Judges "shall be persons of high moral character, impartiality and integrity who possess the qualifications required in their respective countries for appointment to the highest judicial offices. In the overall composition of the Chambers and sections of the Trial Chambers, due account shall be taken of the experience of the judges in criminal law, international law, including international humanitarian law and human rights law." Id.

${ }^{95}$ S. C. Res. 1329, Annex I art. 13, UN Doc S/RES/1329 (2000).

96 See United Nations Convention on the Law of the Sea Annex VI, opened for signature Dec. 10, 1982, 1833 UNTS 397 [hereinafter ITLOS Statute]; Rules of the Tribunal, 28 October 1997 (as amended on 15 March 
American Court provides that judges must be "elected in an individual capacity from among jurists of the highest moral authority and of recognized competence in the field of human rights, who possess the qualifications required for the exercise of the highest judicial functions under the law of the state of which they are nationals or of the state that proposes them as candidates. ${ }^{, 7}$ States may nominate up to two appropriately qualified candidates to the Law of the Sea Tribunal, ${ }^{98}$ three to the Inter-American Court of Human Rights, ${ }^{99}$ and three to the Andean Tribunal of Justice. ${ }^{100}$ When states nominate three candidates to the InterAmerican Court, at least one must be a national of a state other than the nominating state. ${ }^{101}$ In mid-2015, women made up 5\%, 14\%, and 50\% of the judges on ITLOS, IACHR, and ATJ, respectively. Elsa Kelly of Argentina is the only woman ever to have served on ITLOS's 21 -member bench since its establishment. For 20 of the 36 years since the IACHR's founding, women were absent from the bench; most recently, no women served on the bench in 2013 and 2014. 2014 was the first year that two women served on the ATJ simultaneously since its establishment.

States are not required to nominate members of the WTO Appellate Body, but they may forward suggestions to the Director-General. ${ }^{102}$ The

and 21 September 2001, and on 17 March 2009), Doc. ITLOS/8, 17 March 2009; Statute of the Inter-American Court on Human Rights, OAS Res. 448 (DC-O/79), OAS Official Records OEA/Ser P/IX.0.2/80, Vol. 1, at 98 [hereinafter IACHR Statute]; Rules of Procedure of the Inter-American Court of Human Rights, 2000, available at http://www.corteidh.or.cr/regal_ing.pdf. [hereinafter IACHR Rules of Procedure]; American Convention on Human Rights, 22 Nov. 1969, O.A.S.T.S. 36; OAS Off. Rec. OEA/Ser L/V/II 23, Doc. 21, Rev. 6 (1979); reprinted in 9 I.L.M. 673 (1970) [hereinafter American HR Convention];

Andean Subregional Integration Agreement, May 26, 1969, 8 ILM 910 (1969); Treaty Creating the Andean Tribunal of Justice, May 28, 1979, 18 ILM 1203 (1979) [hereinafter ATJ Treaty].

${ }^{97}$ IACHR Statute, supra note 96, art. 4.

${ }^{98}$ ITLOS Statute, supra note 96, art. 4.

${ }^{99}$ IACHR Statute, supra note 96, art. 6. When a slate of three is proposed, at least one of the candidates must be a national of a state other than the nominating state. $I d$.

${ }^{100}$ ATJ Treaty, supra note 96, art. 7.

${ }^{101}$ IACHR Statute, supra note 96, art. 7.

102 Establishment of the Appellate Body, Recommendations by the Preparatory Committee for the WTO, para. 13, WT/DSB/1, approved by the Dispute Settlement Body on February 10, 1995 (June 19, 1995) [hereinafter 
WTO DSU offers no guidance on what procedures delegations should use in coming up with names to propose, even though the United States and the EU always nominate candidates to fill their unofficial reserved spots on the bench. ${ }^{103}$ The United States generally nominates at least two people when proposing individuals to fill its unofficial spot. ${ }^{104}$ A Selection Committee composed of the Director-General, the Chairman of the Dispute Settlement Body, and the Chairmen of the Goods, Services, TRIPS and General Councils then makes proposals for new members "after appropriate consultations." 105 Critiques have been raised concerning the increasing politicization of the WTO AB nominating process, as well as the need to ensure geographic diversity on the bench. ${ }^{106}$ One of seven members of the Appellate Body was a woman in mid-2015. Women were absent from the bench for the first eight years after it was established. Between one and three women have served on the seven-member bench each year since then.

2. Group 2: Greater Amount of Guidance and Transparency

States appointing candidates to the ECJ have received some guidance in the national nomination procedure since $2009 .{ }^{107}$ The Treaty of Lisbon, which entered into force that year, added a new element to the judicial selection procedure consisting of an advisory panel. Article 255 established a panel to "give an opinion on candidates' suitability to perform the duties of Judge and Advocate-General" before the governments make their selections. ${ }^{108}$ The panel, which is appointed by the Council of the

WTO Prep Cmte Recs].

103 Ruth Mackenzie, The Selection of International Judges, in THE OXFORD HANDBOOK OF INTERNATIONAL ADJUDICATION 745 (Cesare P.R. Romano et al., eds. 2014); Joost Pauwelyn, La sélection des juges a l'OMC, et peut-être celle d'un Chinois, mérite plus d'attention, Le Temps (16 Nov. 2007).

${ }^{104}$ Pauwelyn, supra note 103.

${ }^{105}$ WTO Prep Cmte Recs, supra note 102, para. 13.

106 Pauwelyn, supra note 103; see also Manfred Elsig \& Mark A. Pollack, Agents, Trustees, and international courts: The politics of judicial appointment at the World Trade Organization, 0 EURO. J. INT'L REL. 1 (2012); Daniel Pruzin, WTO Selection Panel to Recommence Search For Appellate Body Judge Following Deadlock, International Trade Daily: News Archive (January 21, 2014).

107 Treaty Establishing the European Community art. 221, Nov. 10, 1997, 1997 O.J. (C 340) [hereinafter EC Treaty].

108 Treaty on the Functioning of the European Union art. 255, May 9, 2008, 2008 O.J. (C 115) [hereinafter TFEU Treaty]. 
European Union, is composed of seven members, including former members of the Court of Justice and the General Court, members of national supreme courts, and lawyers of recognized competence, one of whom must be proposed by the European Parliament. ${ }^{109}$ The President of the Court of Justice proposes six of the candidates, and the European Parliament proposes the seventh candidate. ${ }^{110}$ Panel members serve four year terms renewable once. ${ }^{111}$ State members propose judicial candidates to the panel, and the panel may request additional information, holds a private hearing with the candidate, and then prepares an opinion on the candidate's suitability, including a statement of reasons. ${ }^{112}$ The panel then forwards its opinion to member state governments. ${ }^{113}$ There is no guidance on procedures to be followed by states in generating names for the panel's review in the first instance. There is no election process; rather individual states then appoint their nominees to the bench.

In mid-2015 the ECJ was composed of five women and twenty-three men (18\% women). From 1952 until 1999, no woman had ever served on the ECJ's bench. From 1999 until 2008, between one and three women served on the bench. It is interesting to note that the court's membership increased from 15 to 27 during that period, decreasing the percentage of women judges on the bench from $20 \%$ in 2003 , to $11 \%$ in 2008 . Since 2009 , the number of women on the bench has fluctuated between 4 and 5 , ranging from $15 \%$ to $18 \%$ of the total bench.

The European Court of Human Rights has among the most complex selection procedures of the world's international courts, and the history of the evolution in the procedures is important to understanding its current iteration. From 1959 until 1998, the process was relatively simple. According to the text of the original European Convention on Human Rights, the Consultative Assembly was to elect judges to the Court from a list of three candidates provided by Members of the Council of Europe. ${ }^{114}$

${ }^{109} I d$.

${ }^{110}$ Id.; Laurence Burgorgue-Larsen, Between Idealism and Realism: A Few Comparative Reflections and Proposals on the Appointment Process of the Inter-American Commission and Court of Human Rights Members, Working Paper \#1, 14 (May 2014).

${ }^{111}$ European Council Decision Relating to the Operating rules of the Panel Provided for in Article 255 of the Treaty on the Functioning of the European Union (2010/124/EU), Annex, para. 3.

${ }_{112}^{11} I$. at paras. 6-8.

${ }^{113} I d$. at para. 8.

114 European Convention for the Protection of Human Rights and Fundamental Freedoms art. 39, opened for signature Nov. 4, 1950, Europ. 
Candidates were to "possess high moral character and... either possess the qualifications required for appointment to high judicial office or be jurisconsults of recognised competence."115 The Court was to be composed of one judge from each state member of the Council of Europe, and no two judges could be nationals of the same state. ${ }^{116}$ States included no other guidance for national nominations or qualifications requirements in the original convention. The percentage of women judges on the bench during this period fluctuated between $0 \%$ and $11 \%$; it was $3 \%$ in 1998 .

In preparation for the entry into force of Protocol 11, the Parliamentary Assembly adopted resolutions, recommendations and orders with regard to selection procedures. Judges are still elected from lists of 3 candidates submitted by each state party, by the Parliamentary Assembly, ${ }^{117}$ but a much greater focus exists on making national selection procedures transparent and ensuring the election of qualified candidates. In 1996, the Parliamentary Assembly committed itself to improving its procedures for the selection of candidates, adopted a model curriculum vita to systematize the information provided by candidates to the Parliamentary Assembly, and it undertook to require personal interviews of candidates by one of its committees once candidates were nominated. ${ }^{118}$ It also ordered the Committee on Legal Affairs and Human Rights to "examine the question of the qualifications and manner of appointment of judges to the European Court of Human Rights, with a view to achieving a balanced representation of the sexes." ${ }^{119}$ Between 1997 and 1998 the percentage of women on the bench jumped from $3 \%$ to $18 \%$. The percentage of women judges on the court has not fallen below $17 \%$ since then.

T.S. No. 5, 213 U.N.T.S. 221 (entered into force Sept. 3, 1953) [hereinafter ECHR].

${ }^{115} I d$., art. 39.

${ }^{116} I d$., art. 38.

117 Protocol 11, art. 22; European Convention on Human Rights, as amended by Protocols 11, 14, and supplemented by Protocols 1,4, 6, 7,12 , 13 , at art. 22.

${ }^{118}$ On the procedure for examining candidatures for the election of judges to the European Court of Human Rights Parliamentary Assembly of the Council of Europe, Resolution 1082 (1996). Recommendation 1295 (1996) on the procedure for examining candidatures for the election of judges to the European Court of Human Rights.

${ }^{119}$ Procedure for examining candidatures for the election of judges to the European Court of Human Rights, Order 519 (1996); see e.g., Resolution 1200 (1999), Election of judges to the European Court of Human Rights. 
In 1999, the Parliamentary Assembly criticized national selection procedures and proposed criteria for their improvement; ${ }^{120}$ it recommended that the Committee of Ministers invite states to apply the following set of criteria in the preparation of candidate lists:

i. issue a call for candidatures through the specialised press, so as to obtain candidates who are indeed eminent jurists satisfying the criteria laid down in Article 21, paragraph 1, of the Convention; ii. ensure that the candidates have experience in the field of human rights, either as practitioners or as activists in non-governmental organisations working in this area;

iii. select candidates of both sexes in every case;

iv. ensure that the candidates are in fact fluent in either French or English and are capable of working in one of these two languages; $\mathrm{v}$. put the names of the candidates in alphabetical order. ${ }^{121}$

In addition, the Assembly asked the Committee of Ministers to invite member states to consult their national parliaments in the preparation of lists to create a more transparent national selection procedure. ${ }^{122}$ Shortly thereafter, it instructed the Sub-Committee on the Election of Judges of the Committee of Legal Affairs and Human Rights to ensure that states members apply these criteria, "and in particular the presence of candidates of both sexes." 23 In the same vein, in 2004, the Parliamentary Assembly emphasized the importance of an independent judiciary for the protection of human rights and fundamental freedoms, insisted that the appointments process "reflect the principles of democratic procedure, the rule of law, nondiscrimination, accountability and transparency," and it urged states to publish their procedures. ${ }^{124}$

${ }^{120}$ Recommendation 1429(1999), National procedures for nominating candidates for election to the European Court of Human Rights.

${ }^{121}$ Recommendation 1429(1999), National procedures for nominating candidates for election to the European Court of Human Rights.

${ }^{122} \mathrm{Id}$.

123 Order No. 558 (1999), National procedures for nominating candidates for election to the European Court of Human Rights.

${ }^{124}$ Candidates for the European Court of Human Rights, Recommendation 1649 (2004). The Assembly's Recommendation stated: “...it is not satisfactory merely to assert that the gender balance of the Court reflects the under-representation of women in the judiciary of the member states. It is in the interest of impartiality and of the Court's effectiveness for the 
In Resolution 1366 (2004), the Parliamentary Assembly decided it would no longer consider lists of candidates where the areas of competence of candidates appear "unduly restricted," the list does not contain candidates of both sexes, the candidates do not have sufficient knowledge of an official language of the Court, or do not possess "the stature" to meet the qualifications requirements enumerated in article 21 of the European Convention. ${ }^{125}$ The Assembly emphasized its belief in the importance of the transparency of procedures, and it decided to investigate obstacles to nominating women at the national and European levels. ${ }^{126}$ After Malta submitted an all-male list to the Parliamentary Assembly, it sought an Advisory Opinion from the European Court of Human Rights on the requirement for at least one member of the under-represented sex. As a result of the Court's opinion, the Assembly modified its list requirement such that it would only consider single-sex lists where a contracting party has "taken all necessary and appropriate steps" to obtain a list with a candidate of the under-represented sex. ${ }^{127}$ Also, it required various bodies of the Assembly to certify the existence of "exceptional circumstances"

Committee of Ministers, the Assembly, and the high contracting parties to address the issue of the gender imbalance of the Court by considering -and where necessary, improving - the procedures for the appointment of judges." Id. The Parliamentary Assembly then called on the Committee of Ministers to invite member states to meet specific criteria before submitting their candidate lists, including an open call for candidates, candidates with experience in human rights, lists with both sexes, candidates with knowledge of one of the official languages of the Court, and that names of candidates be placed in alphabetical order on candidate lists. It also encouraged the Committee to consider revising the Convention to state that the three-candidate lists include at least one candidate of each sex. Id., paras. 19, 21.

125 Candidates for the European Court of Human Rights, Resolution 1366 (2004).

${ }^{126}$ Id. The Parliamentary Assembly then decided to reintroduce and modify the rule for candidate lists such that it would no longer consider candidates where "the list does not include at least one candidate of each sex, except when the candidates belong to the sex which is underrepresented in the Court, that is the sex to which under $40 \%$ of the total number of judges belong." Candidates for the European Court of Human Rights, Resolution 1426 (2005).

127 Candidates for the European Court of Human Rights, Resolution 1627 (2008). 
permitting a list with no members of the under-represented sex. ${ }^{128}$ Since the Advisory Opinion was issued, states have provided unisex lists on at least two occasions. ${ }^{129}$ In 2009, the Parliamentary Assembly reiterated that national nominations procedures must reflect principles of "democratic procedure, transparency and non-discrimination," it required the Assembly to reject lists that fail to present a "real choice" among the candidates submitted, and allowed the Assembly to reject lists not generated through "fair, transparent and consistent" national selection procedures. ${ }^{130}$

${ }^{128}$ Id. In the wake of the Court's Advisory Opinion, the Assembly modified the list requirement: "Lists of candidates should as a general rule contain at least one candidate of each sex, unless the sex of the candidates on the list is under-represented on the Court (under $40 \%$ of judges) or if exceptional circumstances exist to derogate from this rule." CM(2012)40 addendum final, 4.4 Guidelines of the Committee of Ministers on the selection of candidates for the post of judge at the European Court of Human Rights - Explanatory Memorandum.

${ }^{129}$ See, e.g., List and curricula vitae of candidates submitted by the Government of the Republic of Moldova (Aug. 28 2012), available at http://assembly.coe.int/Documents/WorkingDocs/2012/COE.PACE.WD.C OM.13027.2012.EN.pdf (proposing three male candidates); Letter to the Secretary General of the Parliamentary Assembly from the Belgian Federal Department

of Justice, dated July 7, 2011, available at http://assembly.coe.int/nw/xml/XRef/X2H-Xref-

ViewPDF.asp?FileID=12986\&lang=en (proposing three male candidates).

${ }^{130}$ Resolution 1646 (2009), Nomination of candidates and election of judges to the European Court of Human Rights. The Assembly again listed best practices for selection procedures, such as open calls for candidates and listing candidates in alphabetical order, and "strongly urge[d]" states to establish national selection procedures "to ensure that the authority and credibility of the court are not put at risk by ad hoc and politicised processes" and such that those advising on selection are "themselves as gender-balanced as possible." Id. In 2011, the Parliamentary Assembly specified that when a list lacks a member of the underrepresented sex, twothirds of the Sub-Committee on the Election of Judges to the European Court of Human Rights must determine that the state proposing the list took all "necessary and appropriate steps to ensure" that the list contained candidates of both sexes meeting the qualifications requirements in the European Convention, and the Parliamentary Assembly must also endorse this position. Resolution 1841 (2011), The amendment of various provisions of the Rules of Procedure of the Parliamentary Assembly - 
In 2010, the Committee of Ministers of the Council of Europe established an Advisory Panel of Experts on Candidates for Election as Judge to the European Court of Human Rights to assist states in evaluating candidates before they are transmitted to the Parliamentary Assembly for consideration. ${ }^{131}$ The Panel is composed of seven members chosen from states' highest national courts, former judges of international courts, and lawyers of recognized competence, by the Committee of Ministers in consultation with the President of the Court, and the panel is supposed to be "geographically and gender balanced." 132 States must forward to the Panel the names and curricula vitae of intended candidates before submitting them to the Parliamentary Assembly. If, following consultations with the nominating state, the Panel finds that a nominee is not suitable, it will provide that view and its reasoning confidentially to the state. When three candidates are presented by a state to the Parliamentary Assembly, the Panel will confidentially provide its views in writing as to whether the candidates meet the criteria of the Convention. The first panel consisted of two women and five men. ${ }^{133}$ In June 2014, the Committee appointed a Panel consisting of one woman and six men. ${ }^{134}$

In addition, in 2012, the Committee of Ministers issued detailed guidance on the selection of candidates for ECHR judgeships covering the establishment of procedures, identification of criteria for candidates, composition and procedures of selection bodies, and the role of the final decision-maker to whom selection bodies report. ${ }^{135}$ The Guidelines provide

Implementation of Resolution 1822 (2011) on the reform of the Parliamentary Assembly.

${ }^{131}$ Resolution CM/Res(2010)26.

${ }^{132}$ Id.

${ }^{133}$ Establishment of the Advisory Panel of Experts on Candidates for Election as Judge to the

European Court of Human Rights - Implementation, available at https://wcd.coe.int/ViewDoc.jsp?Ref=CM/Del/Dec(2010)1101/1.7\&Langua ge $=$ lanEnglish $\&$ Ver $=$ original $\&$ Site $=C M \& B$ ackColorInternet $=C 3 C 3 C 3 \& B a$ ckColorIntranet=EDB021\&BackColorLogged=F5D383.

${ }^{134}$ Advisory Panel of Experts on Candidates for Election as Judge to the European Court of Human Rights - Appointment of members, available at https://wcd.coe.int/ViewDoc.jsp?Ref=CM/Del/Dec(2014)1202/1.7\&Langua ge $=$ lanEnglish $\&$ Ver $=$ original $\&$ Site $=C M \& B$ ackColorInternet $=C 3 C 3 C 3 \& B a$ ckColorIntranet=EDB021\&BackColorLogged=F5D383.

${ }^{135} \mathrm{CM}(2012) 40$ addendum final, 4.4 Guidelines of the Committee of Ministers on the selection of candidates for the post of judge at the European Court of Human Rights - Explanatory Memorandum, paras. 2, 
specific examples of best practices. As for the procedure for drawing up recommended lists of candidates, the Committee noted that the composition of selection bodies is an "essential consideration" and it should be free from "undue influence since the composition of the final list of candidates must not be, and must not appear to be a result of political patronage or preference..."136 The committee that evaluates candidates after states submit them to the Parliamentary Assembly also considers whether the state complied with the criteria established by the Assembly, including the presence of the under-represented sex in the list of candidates. ${ }^{137}$

Between 1999 and 2015, the percentage of women on the bench has fluctuated between $17 \%$ in 1999 and 2000, and 40\% in 2011, increasing every year from 2000 until 2011. Since 2011, the percentages have ranged from $33 \%$ to $36 \%$. Women have taken up $29 \%$ of the judicial slots since 1999.

3. Group 3: No National Nomination Procedure

The ECOWAS Court has no national selection procedure at all. The Protocol to the Community Court of Justice states that member states may nominate up to two candidates each, and then Heads of State of member states vote on the nominees. ${ }^{138}$ In 2006, States reformed the judicial selection procedure to give national judges a greater voice in the selection of judges to ECOWAS through a Community Judicial Council, composed of chief justices of states without representation on the Court. ${ }^{139}$ The reform was instituted, also, to "ensure that the Court is endowed with the best qualified and competent persons to contribute, by virtue of their quality and experience" to the development of Community law. ${ }^{140}$ When it is a state's turn to have a judge sit on the Court, the Council initiates a competitive selection process by advertising the vacancies and required qualifications in the Official Gazette of the Community and widely circulated national

$15,16$.

136 Id., para. 48.

${ }^{137}$ Evaluation of the implementation of the reform of the Parliamentary Assembly, Resolution 2002 (2014), paras. 9 \&10, Appendix.

${ }^{138}$ Protocol A/P.1/7/91 on the Community Court of Justice art. 3, July 6, 1991 [hereinafter 1991 Protocol].

${ }^{139}$ Karen J. Alter et al., A New International Human Rights Court for West Africa: The ECOWAS Community Court of Justice, 107 AM. J. INT'L L. 737, 760 (2013).

140 ECOWAS Newsletter, 4 (October 2006), available at http://www.ecowas.int/publications/en/newsletter/ECOWAS_NewsLetter_0 1-Eng.pdf (last visited November 12, 2014). 
gazettes and newspapers. ${ }^{141}$ The Council collects the applications, narrows down the applications to three per state, interviews the three candidates per state, and then recommends one to the Authority. ${ }^{142}$ Interestingly, it appears that the home state of the candidate is no longer formally involved in the nomination process for its candidates to the Court, although candidates without a state's support are unlikely to survive the Authority's vote. ${ }^{143}$ Although, after the Court lost one of its seven judges, women made up 50\% of the bench in 2012 and 2013, by mid-2015, only one woman was serving on the 7 member bench.

\section{Conclusions on National Nominations}

When courts are grouped by the amount of guidance provided to states on national nominations procedures, no clear pattern in the data on sex representativeness emerges. ECOWAS dropped from 50\% to $14 \%$, even though its national nomination procedure appears quite comprehensive, open and focused on merit. The ICJ's percentage of female judges has increased from $0 \%$ to $20 \%$, but there has been no apparent corresponding change to national selection procedures. The ICC has a relatively high number of female judges, but little in the way of guidance for national selection procedures. The ECJ has had an advisory committee on nominations since 2009, but the percentage of female judges is still quite low. On the other hand, the Court with the greatest amount of guidance on national nomination procedures, the ECHR, shows a strong upward trend in female participation. Since the Parliamentary Assembly began emphasizing open and merit-based selection procedures, the percentage of female judges has increased dramatically.

A number of factors make conclusions difficult to draw about the relationship between national nomination procedures and sex representativeness. First, the sample size of twelve courts is relatively small. Second, to some extent, the comparison is one of apples and oranges. Procedures differ across courts, and sometimes suggested or even required guidelines or procedures are not rigorously complied with. Also,

${ }^{141}$ Mojeed Olujinmi Abefe Alabi, Analysis of the Role of the ECOWAS COURT IN REgIONAL INTEGRATION IN WeSt AFRICA 147 (Thesis submitted for the degree of Doctor of Philosophy at the University of Leicester) (2013). An advertisement for a judicial position was even posted on an internet job site: http://m.ngcareers.com/job/2013-10/judge-atnational-judicial-council\#sthash.GIX3Q2vd.sVzCrGir.dpbs (last visited November 14, 2014).

${ }^{142} I d$. at 148 .

${ }^{143} I d$. at $148-49$. 
looking only at national nominations leaves out what happens at the international elections stage, when such a stage exists. Finally, it excludes sex representativeness requirements or aspirations found in a few courts' statutes. What does emerge from the comparison, however, is that, with a few notable exceptions, the vast majority of the courts surveyed have surprisingly little concrete instruction to states at the national nomination stage. Nor are their procedures transparent.

The lack of a transparent procedure for selecting judges on most courts makes it easier for selectors to define the pool of acceptable candidates narrowly and in a way that may benefit them personally. Individuals may select a particular nominee because it will help them gain a professional advantage in the future, or the nominee's pedigree may correspond with the selector's own understanding of merit, based on the selector's own professional choices. It benefits an Oxford graduate to name other Oxford graduates to positions of power because it enhances her own credentials. It may benefit a lawyer to push his client to name a particular individual as ad hoc judge to the International Court of Justice in the hopes that the newly named judge will become a friendly professional acquaintance and reciprocate in some way in the future. Bryant Garth and Yves Dezalay made a similar point in the context of international commercial arbitration: arbitrators and would be arbitrators "promote the forms of symbolic capital that give maximum value to their personal characteristics, but also they try to build symbolic capital that will allow them to prosper and succeed in the changing environment."144 Access to the kinds of experiences that build symbolic capital or prestige may itself be conditioned upon the same incentives to exclude newcomers or individuals with non-traditional backgrounds, as well as flawed selection procedures. For example, four of the last five judges elected to the ICJ were previously members of the International Law Commission, ${ }^{145}$ but very few women have ever served on that body; only 2 of 34 members elected in 2011 were women. ${ }^{146}$

Further, opaque nomination procedures are likely to make it more difficult for less well connected potential candidates to be aware of

144 Yves Dezalay \& Bryant G. Garth, Dealing in Virtue: INTERNATIONAL COMMERCIAL ARBITRATION AND THE CONSTRUCTION OF A TRANSNATIONAL LEGAL ORDER 10, 18 n. 7 (1996).

145 Dapo Akande, Patrick Robinson of Jamaica Elected to the ICJ (November 19, 2014), at http://www.ejiltalk.org/patrick-robinson-ofjamaica-elected-to-the-icj/.

146 Membership, International Law Commission (2012-2016), at http://www.un.org/law/ilc/ (last visited Jan. 19, 2015). 
openings. In a recent book, Ruth Mackenzie, Kate Malleson, Penny Martin and Philippe Sands conducted a series of interviews about selection procedures for the ICJ and the ICC; they determined that "few wellinformed insiders appear to be familiar with the details," and "significant variations in practice from one judicial nomination to another frequently occur." 147 Processes varied substantially from state to state, although most states used "informal" nomination processes, sometimes consisting of discussions among a few individuals, followed by decisions by powerful insiders. ${ }^{148}$ Individuals known to the decision-makers and who lobby for the position are most likely to succeed. ${ }^{149} \mathrm{~A}$ few states appeared to have more structured and transparent procedures, but these were relatively rare. ${ }^{150}$ Overall, processes were "marked by their lack of transparency and accountability and a stronger likelihood of being informed by extraneous political considerations. The resulting selection pool was small, there was limited outside input into the selection process, and political factors, rather than the individual selection criteria, could determine nominations." ${ }^{151}$ In the same vein, in describing the selection of nominees for international courts more generally, Daniel Terris, Cesare P.R. Romano and Leigh Swigart wrote:

In general, one cannot apply to become an international judge. Most of the time one is called. It is not only a matter of having the right skills and experience, but most of all a matter of being on the radar screen of, and appreciated by, one's own government, particularly by some key civil servants. ${ }^{152}$

Similarly, in their interviews of international commercial arbitrators, Dezalay and Garth were told that "It's a mafia because people appoint one another. You always appoint your friends - people you know," and "[i]t is a club. They nominate one another. And sometimes you're counsel, and sometimes you're arbitrator." 153 It is difficult for outsiders to break into the

${ }^{147}$ SELECTING INTERNATIONAL JUDGES, supra note 20, at 64.

${ }^{148} I d$. at 64.

${ }^{149} I d$. at 65 .

${ }^{150} \mathrm{Id}$.

${ }^{151} I d$. at 95.

152 TERRIS, ET AL., supra note 10, at 23. One individual described the process of nominating judges to the ICJ and the ICC as "very direct and personal and not very institutional-like, [more] a friendship thing." SELECTING INTERNATIONAL JUDGES, supra note 20, at 86.

${ }^{153}$ DEZALAY \& GARTH, supra note 144 , at 10. 
club if they lack information about opportunities or if there are no apparent application procedures. And the lack of transparency at the national nomination level precludes accountability or oversight at the domestic level by constituencies who might push for greater diversity or more structured procedures.

In summary, the opacity of national nominations procedures may play a role in reducing potential sex representativeness on the bench. Without information about available positions and opaque procedures, individuals or groups with fewer connections to nominators may simply not be aware of openings or choose to refrain from applying if they believe decisions have already been made. Insiders doing the selection have incentives to validate their own qualifications as they nominate new candidates, and the lack of transparency precludes public accountability.

\section{Elections - May the Best Candidate Win?}

Once a candidate is nominated for an international judgeship, she usually must survive election by states in an international body, although not in every case. For example, individual states appoint their judges to the ECJ. Just as with national nominations, the drafters of the constitutive instruments of international courts have provided varying degrees of direction to states on voting at the international level, in the form of statutory mandates or aspirations, or institutionalized screening mechanisms to evaluate candidates' qualifications or rank candidates. It appears that courts with a high degree of direction, either in the form of express instructions about how to vote or institutionalized screening mechanisms tend to have higher percentages of women judges on the bench. The courts with the greatest amount of direction to states at the international selection phase, as well as screening mechanisms, are the International Criminal Court and the European Court of Human Rights. These are followed by a second group, which includes ECOWAS and the WTO Appellate Body; both courts have screening committees, but little statutory guidance on selecting among candidates. The third group has no institutionalized screening and some statutory guidance, and it includes the AfCHPR, the ICTY and the ICTR. The remainder of the courts - the IACHR, ICJ, ITLOS, and the ATJ - provide the least amount of statutory direction and no institutionalized screening mechanism at the international level. The group with the least amount of statutory direction and no institutionalized screening mechanisms had among the lowest number of women judges historically and the group with the highest amount of screening and direction had a greater proportion of women on the bench. 
1. Group 1: Quotas and Screening

States are provided the most guidance as to how to select among nominees in the International Criminal Court. First, the Statute requires that no two judges be nationals of the same state, ${ }^{154}$ and that state parties must consider the need for representation of the principal legal systems of the world, equitable geographical representation, and "a fair representation of female and male judges." "155 They must consider, too, the need to include judges with legal expertise on specific issues such as violence against women or children. ${ }^{156}$ The President of the Assembly of States Parties may extend the nomination period up to six weeks if regional or gender minimum voting requirements are not matched with at least twice the number of candidates fulfilling the requirement. ${ }^{157}$

Judges are elected at a meeting of the Assembly of State Parties by secret ballot. ${ }^{158}$ The persons elected are the candidates who obtain the highest number of votes and a two-thirds majority of the States present and voting. ${ }^{159}$ Two lists of candidates are generated in advance of the vote. List A contains candidates with criminal law and procedure expertise, while List B contains candidates with relevant international law knowledge. ${ }^{160}$ States are instructed to vote such that at least 9 and no more than 13 candidates from list $\mathrm{A}$ and at least 5 and no more than 9 candidates from list B are seated on the Court at all times. ${ }^{161}$ Further, each state party is required to vote for a minimum number of candidates from each regional group and of each gender, and the required number of votes decreases depending on the number of candidates available and the number of judges meeting those requirements remaining on the bench. ${ }^{162}$ Only ballots complying with the voting requirements are valid. ${ }^{163}$ Elections continue until all spots are filled.

The Assembly of State Parties created an Advisory Committee on Nominations to assist states in vetting nominees for judgeships in 2011 . $^{164}$

${ }^{154}$ Rome Statute, supra note 82, art. 36(7).

${ }^{155}$ Id., art. 36(8)(a)(iii).

${ }^{156} I d$., art. 36(8).

${ }^{157}$ Procedure for nomination to ICC, supra note 84, para. 11.

${ }^{158}$ Rome statute, supra note 82, art. 36(6)(a).

${ }^{159} \mathrm{Id}$.

${ }^{160}$ Rome Statute, supra note 82, art. 36(5).

${ }^{161}$ Procedure for nomination to ICC, supra note 84, para. 20.

${ }^{162}$ Id.

${ }^{163} I d$., para. 22.

${ }^{164}$ Res. ICC-ASP-10-Res.5-ENG, paras. 19-20 (Dec. 21, 2011). In the 
The Advisory Committee evaluates whether nominees proposed by states meet the requirements of the Rome Statute. ${ }^{165}$ Despite a mandate for geographically and gender diverse membership, the Assembly of State Parties ultimately elected a geographically diverse group of eight men and one woman to serve on the Committee in October 2012. ${ }^{166}$ The Committee has conducted interviews with nominees and reached conclusions about their proficiencies in the working languages of the Court and the extent of their relevant knowledge and experience. ${ }^{167}$ A candidate whose qualifications were questioned by the Advisory Committee was not elected to the bench in 2013. ${ }^{168}$ Of all the courts surveyed, the ICC has had the highest percentage of women judges of surveyed courts, reaching $61 \%$ in 2009, and at or exceeding $39 \%$ for its entire existence.

Like the ICC, the ECHR too has an institutional mechanism for reviewing candidates before they are voted on by the Parliamentary Assembly, in addition to the Advisory Panel of Experts on Candidates for Election as Judge to the ECHR created by the Council of Ministers to advise states parties before naming nominees, discussed above. In 1996, the Assembly requested that states utilize a standardized CV to facilitate the comparison of candidates, and it expressed its expectation that the SubCommittee on Human Rights or an ad hoc sub-committee of the Committee on Legal Affairs and Human Rights would interview all candidates on

same resolution, the Assembly of the State Parties encouraged States Parties "to conduct thorough and transparent processes to identify the best candidates" for judgeships. Id.

165 Report of the Bureau on the Establishment of an Advisory Committee on Nominations of judges of the International Criminal Court, Tenth Session, U.N. Doc. ICC/ASP/10/36 (Dec. 21, 2011).

166 Election of the Advisory Committee on Nominations - 2012 Nomination, International Criminal Court, available at http://www.icccpi.int/en_menus/asp/elections/advisorycommitteenominations/Pages/electi on\%20acn-\%202012.aspx (last visited Apr. 30, 2014).

${ }^{167}$ Report of the Advisory Committee on Nomination of Judges on the work of its Second Meeting, Twelfth Session, U.N. Doc. ICC/ASP/12/47, Para. 10 (Oct. 29, 2013) available at http://www.icccpi.int/iccdocs/asp_docs/ASP12/ICC-ASP-12-47-ENG.pdf.; Id., Annex 2.

168 Id.; Current Judges, International Criminal Court, available at http://www.icc-

cpi.int/en_menus/icc/structure $\% 20$ of $\% 20$ the $\% 20$ court/chambers/the $\% 20 j u d$ ges/Pages/the\%20judges\%20\%20\%20biographical\%20notes.aspx (last visited Jan. 10, 2014) (listing Judge Geoffrey A. Henderson as a sitting judge of the ICC). 
behalf the Parliamentary Assembly. ${ }^{169}$ The sub-committee's conclusions were then forwarded to the Assembly before the vote. ${ }^{170}$ As of January 2015, the Subcommittee will be replaced by a Committee on the Election of Judges to the European Court of Human Rights. ${ }^{171}$ The new committee, composed of twenty people, is charged with studying the standardized CVs of all candidates, interviewing candidates, preparing a report to the Assembly with a recommendation and a ranking of candidates, along with the reasons for its recommendations and rankings, and seeking to ensure that the nominating state complied with the Assembly's criteria for the establishment of lists, "and in particular the presence of candidates of both sexes." 172 The committee may also report to the Assembly on any questions related to the national selection procedure. ${ }^{173}$ Any decision to reject a list of candidates or to consider a single-sex list of candidates requires a two-thirds majority of votes cast. ${ }^{174}$ When the committee chooses to recommend rejection of a list, it must provide its reasons to the Assembly. ${ }^{175}$ Committee members are expected to have "appropriate knowledge or practical experience in the legal field." ${ }^{176}$ Women have accounted for between $33 \%$ and $40 \%$ of the bench for the period of 2008 to 2015, among the highest percentages for all the courts surveyed.

2. Group 2: Screening and Ranking, But Little Statutory Guidance

${ }^{169}$ On the procedure for examining candidatures for the election of judges to the European Court of Human Rights, Eur. Parl. Assemb., 1996 Sess., $\quad$ Res. $1082 \quad$ (1996), available at http://assembly.coe.int/Mainf.asp?link=/Documents/AdoptedText/ta96/ERE S1082.htm.

${ }^{170}$ Election of judges to the European Court of Human Rights, Eur. Parl. Assemb., 1999 Sess., Res. $1200 \quad$ (1999), available at http://assembly.coe.int/Mainf.asp?link=/Documents/AdoptedText/ta99/ERE S1200.htm.

${ }^{171}$ Evaluation of the implementation of the reform of the Parliamentary Assembly, Eur. Parl. Assemb., 2002 Sess., Res. 2002 (2014), available at http://assembly.coe.int/nw/xml/XRef/X2H-Xref-

ViewPDF.asp?FileID=21049\&lang=en.

${ }^{172}$ Evaluation of the implementation of the reform of the Parliamentary Assembly, Eur. Parl. Assemb., 2014 Sess., Res. 2002 (2014) available at http://assembly.coe.int/nw/xml/XRef/X2H-Xref-

ViewPDF.asp?FileID=21049\&lang=en.
${ }^{173} \mathrm{Id}$.
${ }^{174} \mathrm{Id}$.
${ }^{175} \mathrm{Id}$.
${ }^{176} I d$. 
ECOWAS and the WTO Appellate Body have screening and ranking committees, but little statutory guidance to states about how to select among candidates. At ECOWAS, the Community Judicial Council composed of chief justices of states without representation on the Court is charged with ensuring that the Court is endowed with the best qualified and competent persons to contribute, by virtue of their quality and experience" to the development of Community law. ${ }^{177}$ The Council not only collects applications, but also, it narrows down the applications to three per state, interviews the three candidates per state, and then recommends one candidate to states for a vote. ${ }^{178}$

The WTO appears to have a relatively rigorous vetting procedure before states vote on members of the Appellate Body. Once states propose candidates, a Selection Committee composed of the Director-General, the Chairman of the Dispute Settlement Body, and the Chairmen of the Goods, Services, TRIPS and General Councils makes proposals for new members. ${ }^{179}$ The Selection Committee requires candidates to take a written exam and to participate in an interview process. ${ }^{180}$ Then, member states vote on the proposed slate of candidates. ${ }^{181}$ Most, if not all of the time, candidates proposed by the Selection Committee are elected. ${ }^{182}$ Despite the apparently in-depth interview process in the Committee, some have criticized the late announcement of candidates by the Committee to the public, and a corresponding lack of public debate about potential candidates. $^{183}$ In early 2014 , elections were delayed after the Committee deadlocked over whom to propose, in response to pressure from African countries for an African member of the Body, and US opposition to the proposed candidates. ${ }^{184}$

${ }^{177}$ Alter et al., supra note 139, at 760. ECOWAS Newsletter, 4 (October 2006), available at http://www.ecowas.int/publications/en/newsletter/ECOWAS_NewsLetter_0 1-Eng.pdf (last visited November 12, 2014).

${ }^{178}$ ABEFE ALABI, supra note 141, at 148 .

${ }^{179}$ WTO Prep Cmte Recs, supra note 102,para. 13.

${ }^{180}$ Pauwelyn, supra note 103.

${ }^{181}$ Dispute Settlement Understanding, supra note 31, art. 17. Appellate Body Members, World Trade Organization, http://www.wto.org/english/tratop_e/dispu_e/ab_members_descrp_e.htm (last visited June 11, 2014).

${ }^{182}$ Pauwelyn, supra note 103.

${ }^{183} \mathrm{Id}$.

${ }^{184}$ Pruzin, supra note 106. 
In mid-2015, 14\% of sitting ECOWAS judges were women, and $14 \%$ of Appellate Body members were women in mid-2015. One out of seven judges on each bench was a woman. Women have occupied $14 \%$ of Appellate Body member slots since its establishment, while women accountted for $40 \%$ of ECOWAS judgeships since establishment.

3. Group 3: Some Statutory Guidance, But No Screening

Once state nominees to the African Court on Human and Peoples' Rights arrive at the Assembly of Heads of State and Government of the African Union, states elect judges to the court by secret ballot. ${ }^{185}$ The Assembly must ensure that "there is representation of the main regions of Africa and of their principal legal traditions," as well as "adequate gender representation." 186 There is no formal nominating commission or advisory panel required in the nomination of judges at the national level or for vetting candidates once nominated.

The Secretary-General of the United Nations forwards nominees for permanent judgeships to the ICTY and the ICTR to the Security Council, which then establishes a list of candidates, "taking due account of the adequate representation of the principal legal systems of the world." ${ }^{187}$ No additional guidance is provided as to how the Security Council creates the list of candidates from the names forwarded to it. The General Assembly then votes on the candidates provided by the Security Council; if two candidates of the same nationality receive more than an absolute majority of votes, the one with the greater number of votes will win. ${ }^{188}$ The constitutive instruments also state that "[i]n the overall composition of the Chambers and sections of the Trial Chambers, due account shall be taken of the experience of the judges in criminal law, international law, including international humanitarian law and human rights law."189 For ad litem judges, once states have nominated candidates "taking into account the importance of a fair representation of female and male candidates," the Secretary-General forwards the nominees to the Security Council, which establishes a list of candidates "taking due account of the adequate representation of the principal legal systems of the world and bearing in

${ }^{185}$ Protocol to African Charter, supra note 89, art. 14.

${ }^{186} I d$., art. 14(2), (3).

${ }^{187}$ ICTY Statute, supra note 43, art. 13 bis; ICTR statute, supra note 43, art. 12.

${ }^{188}$ ICTY Statute, supra note 43, art. 13; ICTR Statute, supra note 43, art. 12 .

${ }^{189}$ ICTY Statute, supra note 43, art. 13; ICTR Statute, supra note 43, art. 12 . 
mind the importance of equitable geographical distribution." ${ }^{\text {"190 }}$ Then, whichever candidates receive an absolute majority of votes of the General Assembly are elected. ${ }^{191}$

The African Court on Human and Peoples' Rights was composed of $18 \%$ women judges in mid-2015. Women have occupied two of the 11 positions on that court every year since its establishment. In mid-2015, the ICTY and the ICTR had $11 \%$ and $22 \%$ female permanent judges, respectively, and $0 \%$ ( 0 out of 1 ) and $33 \%$ ( 1 out of 3 ), ad litem judges, respectively. On the ICTY, women occupied ad litem slots $41 \%$ of the time since establishment, and $13 \%$ of the permanent slots. ${ }^{192}$ On the ICTR, women occupied ad litem slots $35 \%$ of the time, and permanent slots $21 \%$ of the time.

\section{Group 4: No Screening and Little Statutory Guidance}

There are no institutional mechanisms for evaluating or ranking nominees at the Inter-American Court of Human Rights, the International Tribunal for the Law of the Sea, the Andean Tribunal of Justice, or the ICJ, although they do have some requirements for voting related to geographic distribution of judges. After states nominate candidates to the InterAmerican Court of Human Rights, parties to the American Convention on Human Rights vote by secret ballot on the candidates. ${ }^{193}$ No two judges can be nationals of the same state. ${ }^{194}$ Nonetheless, in 2015, the Open Society Justice Initiative, supported by over 70 non-governmental organizations, convened a panel of independent experts to review and comment on candidates for the Inter-American Court and Commission of Human Rights. ${ }^{195}$ The panel surveyed the application materials, asked candidates to

${ }^{190}$ ICTY Statute, supra note 43, art. 13ter

${ }^{191} I d$.

192 These statistics were obtained by adding up the total number of slots in which women judges served since the courts were established and dividing it by the total number of slots in which both male and female judges served since establishment.

${ }^{193}$ IACHR Statute, supra note 96, arts. 6-9; American Convention on Human Rights arts. 53-54, opened for signature Nov. 22, 1969, OEA/Ser.K/XVI/1.1, doc. 65, rev. 1 corr. 1 (1970) (entered into force July 18, 1978), reprinted in 9 I.L.M. 673 (1970) [hereinafter American Convention]. States choose their own ad hoc judges when appropriate, and there is no vote required by states parties to the Inter-American Court. IACHR Statute, supra note 96, art. 10.

${ }_{195}^{194}$ IACHR Statute, supra note 96, art. 4.

195 Press Release, Open Society Justice Initiative, New Independent 
complete a questionnaire, looked at publicly available information on each candidate, and opined on the suitability of the various candidates. ${ }^{196}$ For the International Tribunal for the Law of the Sea, after states nominate candidates, states parties vote by secret ballot as well. To be elected, nominees must obtain the largest number of votes and a two-thirds majority of states present and voting, so long as the majority includes a majority of states parties. ${ }^{197}$ No two members of the tribunal can share nationality, and there must be at least three members from each geographical group established by the United Nations General Assembly. ${ }^{198}$ The ITLOS Statute also provides that "[i]n the Tribunal as a whole the representation of the principal legal systems of the world and equitable geographical distribution shall be assured." 199

Once states nominate candidates to the ICJ, the General Assembly and the Security Council independently vote on the candidates. ${ }^{200}$ Candidates who receive an absolute majority of votes in both chambers are elected. ${ }^{201}$ Traditionally, candidates proposed by the permanent members of the Security Council always get elected. ${ }^{202}$ States may not elect two nationals of the same state. ${ }^{203}$ The ICJ Statute provides that "electors shall bear in mind not only that the persons to be elected should individually possess the qualifications required, but also that in the body as a whole the representation of the main forms of civilization and of the principal legal systems of the world should be assured." 204 For the Andean Tribunal of Justice, each state nominates three candidates, and then each judge must be

Panel Will Monitor Election of Inter-American Human Rights Commissioners and Judges (April 29, 2015), available at http://www.opensocietyfoundations.org/press-releases/new-independentpanel-will-monitor-election-inter-american-human-rights-commissioners.

${ }^{196}$ See Independent Panel Report, supra note 69.

${ }^{197}$ ITLOS Statute, supra note 96, art. 4.

${ }^{198} I d$., art. 3

${ }^{199} I d$., art. 2. There is no vote required for ad hoc judges appointed by states when relevant. ITLOS, art. 17.

$$
{ }^{200} \mathrm{Id} \text {. }
$$

${ }^{202}$ MaCKenzie et AL., The Manual on InTERnational Courts AND TRIBUNALS 7 (2010).

${ }^{203}$ ICJ Statute, supra note 79, art. 3. Ad hoc judges are appointed by states without a vote, but "[s]uch person shall be chosen preferably from among those persons who have been nominated as candidates" to permanent judge positions. Id., art. 9 .

${ }^{204} I d$., art. 9. 
unanimously selected by all four contracting parties. ${ }^{205}$ No commission is involved in vetting candidates or providing guidelines to states in voting at the international level.

These courts have among the lowest numbers of women on the bench historically. Women have occupied following percentage of slots on these courts: IACHR $-10 \%$, ITLOS $-2 \%$, the ICJ $-3 \%$, the Andean Tribunal $-12 \%$, and the AfCHPR - 18\%. Nonetheless, the Andean Tribunal currently has $50 \%$ women judges on its four-member bench.

$* * *$

Just as reading constitutive instruments alone does not provide a complete picture of national nominations procedures, neither does a survey of formal elections procedures at the international level. Despite the highminded qualifications language found in many courts' founding documents, states' decisions about whom to vote for appear to be rooted in political horse-trading, rather than merit. ${ }^{206}$ In a study of judges on the ICTY and ICTR, Michael Bohlander determined that eight out of 25 judges at the ICTY and the appeals chamber shared with the ICTR had no prior criminal judicial experience, many of them had no experience in international criminal law, and many did not have even fifteen years of relevant professional experience. $^{207}$ In the same vein, the International Bar Association expressed concerns that, for many courts, "there is no prior consideration of whether candidates for appointment to international judicial office conform to the requirements for appointment according to any stated criteria." 208 And seats on international benches are often seen as "bargaining chips in the diplomatic process," where individuals receive votes because of the lobbying efforts and power of their states, not because of their individual achievements. ${ }^{209}$ Scholars have noted states' difficulty in

${ }^{205}$ ATJ Treaty, supra note 96, art. 7.

206 TERRIS ET AL., supra note 10, at 34 ; SELECTING InTERNATIONAL JUDGES, supra note 20, at 77 ("Success depends to a large extent on vote trading and campaigning..."); Id. at 102.

207 Michael Bohlander, The International Criminal Judiciary Problems of Judicial Selection, Independence and Ethics, in INTERNATIONAL CRIMINAL JUSTICE: A CRITICAL ANALYSIS OF INSTITUTIONS AND PROCEDURES 354 (Michael Bohlander, ed. 2007).

${ }^{208}$ International Bar Association's Human Rights Institute, Background Paper to the Institute's Resolution on the Values Pertaining to Judicial Appointments to International Courts and Tribunals, para. 6 (31 October 2011) [hereinafter IBA's Background Paper].

${ }^{209}$ TERRIS, ET AL., supra note 10, at 34. 
verifying independently the qualifications of proposed candidates. ${ }^{210}$ Political factors appear to play "the important, if not central, role" in elections, at least where the ICJ and the ICC are concerned. ${ }^{211}$ The International Bar Association summarized the state of play with respect to international court and tribunal elections succinctly: "Geopolitical considerations - rather than objective merits, experience, qualifications and personal qualities of the candidates - predominate in the final process." 212

To what extent does this lack of emphasis on qualifications and merit at the international level potentially affect diversity on the bench? By the time states are voting, the candidates have already been nominated. Yet a comparison of procedures to elect judges at the international level suggests that courts with institutionalized screening procedures may have greater numbers of women on the bench. Three of the four courts that utilize committees to screen candidates had relatively high numbers of female judges in mid-2015, or high percentages of slots allocated to women since 1999, or since establishment, whichever came later. These include the ICC $(39 \%, 47 \%)$, the ECHR $(33 \%, 29 \%)$, and ECOWAS $(14 \%, 40 \%)$. The WTO Appellate Body, however, had only $14 \%$ women judges in mid-2015, and $17 \%$ of judicial slots went to women. The courts with the lowest percentages of slots allocated to women since establishment included those with the least amount of institutional screening, such as the IACHR (10\%), ITLOS (2\%), the ICJ (3\%), and the Andean Tribunal of Justice (12\%). Women have served in only six percent of available slots on the ECJ, which has no international voting procedure at all. Although it is difficult to disentangle national nominations procedures, screening mechanisms, and emphasis on equal representation on the bench in constitutive instruments, the data suggest a correlation may exist between institutionalized screening and guidance at the international voting stage and a more sex representative bench.

The extent to which non-governmental organizations and other stakeholders are involved in the screening of candidates and the degree of candidate information accessible to the public may also affect the composition of the bench. A systematic study of NGOs' role in international judicial selection procedures is necessary to better understand their effect. Nonetheless, NGOs appear to be involved in screening candidates when information is available to them. For example, the Coalition for the International Criminal Court has provided its own questionnaire to ICC candidates, interviewed candidates, and held public

\footnotetext{
${ }^{210} I d$. at $34-35$.

${ }^{211}$ SELECTING InTERNATIONAL JUdGeS, supra note 20, at 101.

${ }^{212}$ IBA Background Paper, supra note 208.
} 
events with candidates and experts and public debates among the candidates "to expand on their respective qualifications and expertise, as well as to promote fully-informed decision-making by States Parties delegates." 213 Other NGOs have pushed for greater transparency and procedures at the national nomination and international levels. For example, Human Rights Watch complained about the selection procedures utilized by Russia in generating its list of candidates for the ECHR in 2012. ${ }^{214}$ Civil society organizations urged states to use more rigorous, open, transparent and participatory procedures in national nominations to the African Court on Human and Peoples' Rights. ${ }^{215}$ The Open Society Justice Initiative and over 70 NGOs have pushed for greater transparency and screening of InterAmerican Court candidates. ${ }^{216}$ Others have complained that the late listing of WTO Appellate Body member candidates precludes substantive public debate about their merits. ${ }^{217}$

\section{Sex Representation Requirements}

What about sex representation aspirations or requirements at the national nomination or international election levels? Aspirational statements encouraging states to nominate both men and women may not be as successful as mandates to do so. For example, states parties to the African Court on Human and Peoples' Rights are supposed to give "[d]ue consideration" to "adequate gender representation in the nomination process." ${ }^{218}$ But no binding statutory guidance explains to states how they should implement this mandate, and it is doubtful whether states are taking to heart the African Union Commission's suggestions to include civil society and enhance transparency, or even to nominate women in the first place. The percentage of women judges on the court has been stuck at $18 \%$

213 Delivering on the promise of a fair, effective and independent Court $>$ Election of ICC and ASP Officials > Judges, available at http://www.iccnow.org/?mod=electionjudges (last visited December 15, 2014).

214 Letter to the European Court of Human Rights Regarding the Selection Procedure for Candidates from the Russian Federation from Hugh Williamson, Executive Director, Europe and Central Asia Division, Human Rights Watch, available at http://www.hrw.org/news/2012/04/11/lettereuropean-court-human-rights-regarding-selection-procedure-candidatesrussian- .

${ }^{215}$ See supra [].

216 Independent Panel Report, supra note 69.

${ }^{217}$ Pauwelyn, supra note 103.

${ }^{218}$ Protocol to African Charter, supra note 89, art. 12. 
since its establishment through 2015.

On the other hand, $41 \%$ of ad litem judicial slots on the ICTY have gone to women, while women have occupied only $13 \%$ of permanent judge spots. The numbers are $35 \%$ and $21 \%$, respectively, for the ICTR. States are required to take into account the need for a fair representation of both sexes only with respect to ad litem judges, suggesting that the representativeness requirement at the national nomination stage may make a difference. Like the African Court, however, no guidance exists as to how this mandate should be implemented. The historical data on these courts, found at Figures 9 and 10, appears compelling, nonetheless. It shows that since ad litem judges were added to the ICTY in 2001, women have always served in a significantly higher percentage of ad litem positions than permanent ones. Similarly, women accounted for a greater percentage of ad litem than permanent judges on the ICTR, almost every year since ad litem judges were added in 2004, and until the number of ad litem judges was reduced to only one in 2013.

Mandatory or virtually mandatory requirements to include both sexes at the bench appear to correlate with a dramatically higher percentage of women on the bench. Women have made up at least $39 \%$ of the International Criminal Court every year since its establishment, and the ICC has what amounts to a quota requirement at the international election stage. As for the European Court of Human Rights, almost immediately after the Parliamentary Assembly began drawing states' attention to the issue of sex representation on the bench in 1996, the number of women elected rose dramatically. The percentage of women judges jumped from $3 \%$ to $18 \%$ between 1997 and 1998. Then, shortly after the Parliamentary Assembly invited the Committee of Ministers to encourage states to apply a set of criteria to national nominations in 1999, including open calls for candidates, experience in human rights, and candidates of both sexes, ${ }^{219}$ the percentage of women judges again increased, this time, from 17\% in 1999 and 2000, to $22 \%$ in 2001. This jump coincided with a Parliamentary Assembly instruction to the relevant Parliamentary Assembly subcommittee on elections to ensure that member states apply the stated criteria. ${ }^{220}$ In 2004, the Parliamentary Assembly decided it would no longer consider unisex lists of candidates; ${ }^{221}$ the percentage of women judges rose from $23 \%$ in

${ }^{219}$ Recommendation 1429(1999), National procedures for nominating candidates for election to the European Court of Human Rights.

220 Order No. 558 (1999), National procedures for nominating candidates for election to the European Court of Human Rights.

${ }^{221}$ Candidates for the European Court of Human Rights, Resolution 1366 (2004). 
2004 to $40 \%$ seven years later. Although Malta challenged the list requirement and states have submitted unisex male lists on at least two occasions, ${ }^{222}$ the percentage of women judges has not dropped below $33 \%$ since 2008, four years after the requirement was imposed.

Figure 15 shows the percentage of slots per year filled by women judges from 1999 to 2015, or since establishment until 2015, if the Court was founded after 1999. Interestingly, of the five courts with the highest percentages of slots allocated to women, four had either quotas or aspirational language to include women on the bench: the ICC, the ICTY for ad litem judges, the ICTR for ad litem judges, and the ECHR. Of the seven courts with the lowest percentages of slots going to women, none had quotas or aspirational language seeking a fair representation of women on the bench.

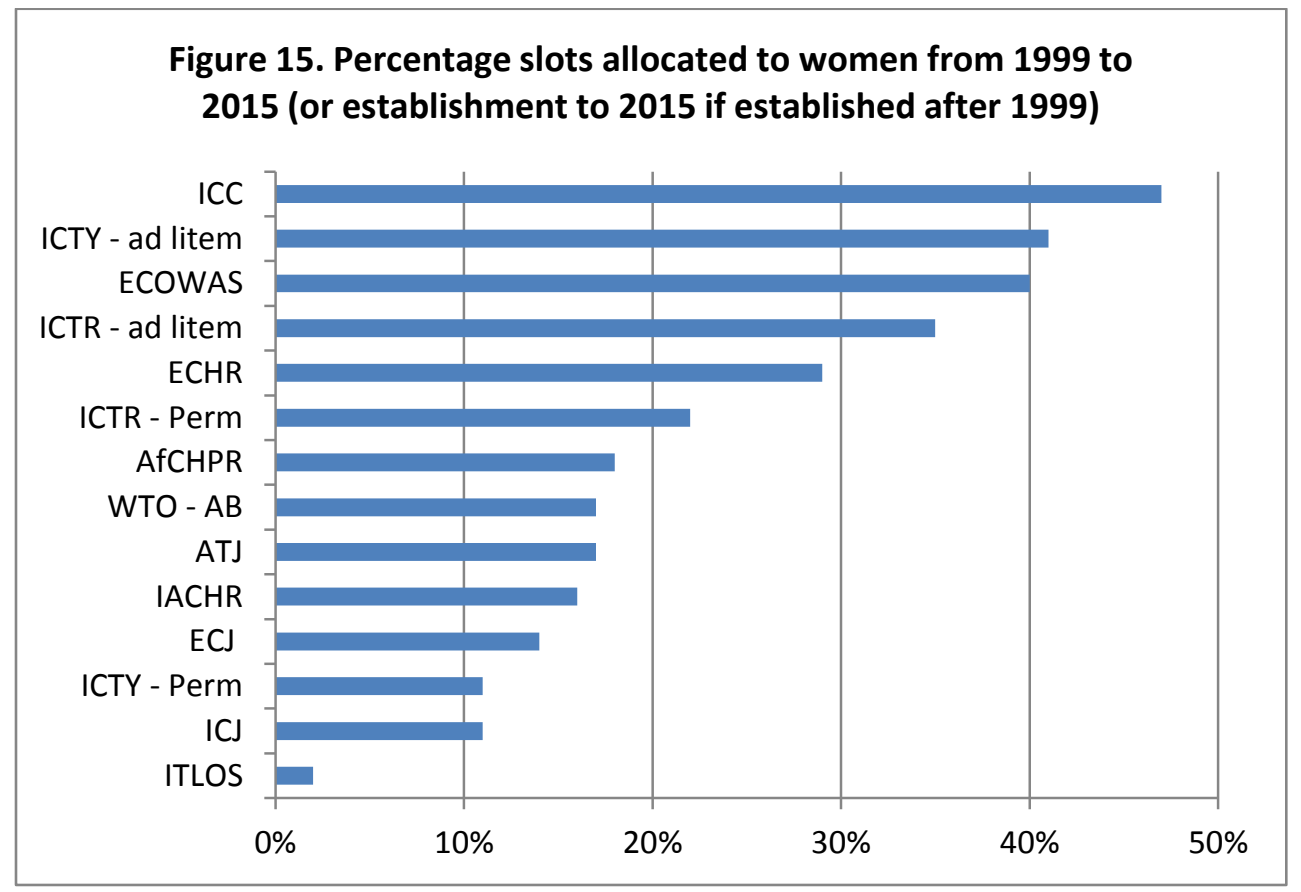

222 See, e.g., List and curricula vitae of candidates submitted by the Government of the Republic of Moldova (28 Aug. 2012), available at http://assembly.coe.int/Documents/WorkingDocs/2012/COE.PACE.WD.C OM.13027.2012.EN.pdf (proposing three male candidates); Letter to the Secretary General of the Parliamentary Assembly from the Belgian Federal Department

of Justice, dated 7 July 2011, at http://assembly.coe.int/nw/xml/XRef/X2H-Xref-

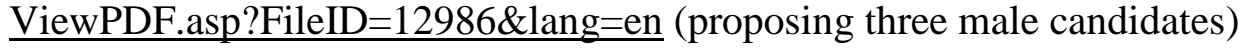


Table 2 shows the percentage of women judges on international courts in mid-2015, comparing courts with sex representation requirements or aspirational language. Table 3 shows those courts without such requirements. While women account for $15 \%$ of judges on courts without sex representation requirements, they make up $32 \%$ of judges on courts with such requirements or aspirational language

Table 2. Female Participation on Courts without Sex Representativeness Requirements (mid-2015)

\begin{tabular}{|c|c|c|c|c|c|c|c|c|c|}
\hline ICJ & $\begin{array}{l}\text { ITLO } \\
\mathrm{S}\end{array}$ & $\begin{array}{l}\text { IACH } \\
\text { R }\end{array}$ & ECJ & ATJ & $\begin{array}{l}\text { ECOW } \\
\text { AS }\end{array}$ & $\begin{array}{l}\text { WT } \\
\text { O } \\
\text { AB }\end{array}$ & $\begin{array}{l}\text { ICT } \\
\text { R } \\
\text { per } \\
\text { m. }\end{array}$ & $\begin{array}{l}\text { ICT } \\
\text { Y } \\
\text { per } \\
\text { m. }\end{array}$ & Total \\
\hline $\begin{array}{l}3 / 1 \\
5 \\
= \\
20 \\
\%\end{array}$ & $\begin{array}{l}1 / 21 \\
=5 \%\end{array}$ & $\begin{array}{l}1 / 7 \\
= \\
14 \%\end{array}$ & $\begin{array}{l}5 / 28 \\
=18 \\
\%\end{array}$ & $\begin{array}{l}2 / 4 \\
=50 \\
\%\end{array}$ & $\begin{array}{l}1 / 7 \\
=14 \%\end{array}$ & $\begin{array}{l}1 / 7 \\
=14 \\
\%\end{array}$ & $\begin{array}{l}2 / 9 \\
\text { per } \\
\text { m. }= \\
22 \%\end{array}$ & $\begin{array}{l}2 / 19 \\
\text { per } \\
\mathrm{m} . \\
= \\
11 \%\end{array}$ & $\begin{array}{l}18 / 11 \\
7= \\
15 \%\end{array}$ \\
\hline
\end{tabular}

Table 3. Female Participation on Courts with Representativeness Requirements (mid-2015)

\begin{tabular}{|l|l|l|l|l|l|}
\hline ICC & $\begin{array}{l}\text { ICTY ad } \\
\text { litem }\end{array}$ & $\begin{array}{l}\text { ICTR ad } \\
\text { litem }\end{array}$ & ECHR & $\begin{array}{l}\text { Af. Ct } \\
\text { HPR }\end{array}$ & Total \\
\hline $7 / 18$ & $1 / 3$ & $0 / 1$ & $15 / 45$ & $2 / 11$ & $25 / 78=$ \\
$=39 \%$ & $=25 \%$ & $=0 \%$ & $=33 \%$ & $=18 \%$ & $32 \%$ \\
\hline
\end{tabular}

Although, due to the small number of courts involved, these comparisons are not statistically significant, they provide compelling circumstantial evidence that quotas and aspirational language may make a difference in getting women on the bench. At the same time, two of the five courts with sex representation requirements, the ICC and the ECHR, also happen to have among the most guidance and screening at the international election level, and the ECHR provides meaningful instruction to states at the national nomination stage. Also, ECOWAS and the WTO appear to have screening and ranking before elections take place, yet the percentage of women judges was relatively low on both courts' benches in mid-2015. Nonetheless, $40 \%$ of slots have gone to women on ECOWAS since it was 
established. $17 \%$ have gone to women on the WTO Appellate Body since establishment.

\section{E. Summarizing the Reasons for the Paucity of Women on the Bench}

The limited pool argument does not adequately explain the paucity of women judges on international courts. It assumes that selection procedures are implemented to select the most meritorious candidates, yet ample evidence exists that political horse-trading, political patronage and other considerations may trump. Also, given the low number of international judgeships available, only a small pool of women is necessary to achieve parity on the bench. Finally, states that appear to have greater pools do not necessarily nominate more women than states with smaller pools, suggesting that something other than the pool is playing a significant role in judicial nominations. Opaque nominations procedures at the national level likely create obstacles for less well-connected or "outsider" candidates to make it through to the next stage of the elections process. Despite the political nature of elections at the international level, courts with institutional screening mechanisms may draw greater numbers of women to the bench. Finally, courts with explicit requirements for sex representativeness have been more successful at achieving it than courts without such provisions.

Other factors aside from or instead of national nomination procedures, institutional screening mechanisms, and representativeness mandates may also be at play, particularly with regard to historical statistics. These may include when the court was established, changes in attitudes toward women, and greater participation in the workforce over time. Since fewer women were qualified to serve as judges in the 1950s than today, older courts would appear more likely to have fewer women as a percentage of the bench since establishment. Also, all the courts with representativeness mandates or aspirations began functioning after 1990, excluding the ECHR, where a sex representation requirement was instituted in 2004. Nonetheless, ITLOS is among the younger courts, and it has among the lowest percentages of women on the bench historically.

Interestingly, all courts with representativeness requirements are human rights or international criminal courts, raising the question whether subject matter jurisdiction might make some sort of difference, rather than statutory language. Just as states are happy to appoint a plethora of women to the CEDAW monitoring body, perhaps states are more willing to nominate and vote for women candidates on courts deciding international human rights and criminal law issues, which may be perceived to implicate what may be deemed "women's concerns." On the other hand, perhaps the willingness exists in theory alone: the Inter-American Court of Human 
Rights has only one woman on the bench, and the African Court appears to be stuck at a maximum of two.

A lack of state and domestic constituencies' commitment to diversity on international court benches may, too, contribute to keeping benches homogeneous. While such a disposition may have helped to diversify the United States federal judiciary, ${ }^{223}$ it is not readily discernable at the international level for many international courts. In their interviews of judges and individuals involved in judicial selection for the International Court of Justice and the International Criminal Court, Mackenzie and her colleagues found that interviewees expressed mixed views about the importance of sex representation on the bench. One questioned the need for emphasizing gender given the increased enrollment of women on law faculties in the West. Others expressed concerns that appointing female candidates would result in a drop in quality of judges. Still others challenged the use of the gender quotas on the ICC, suggesting that it was unfair that seven seats went to women in the first ICC election. While the requirements for legal, linguistic and geographical diversity were widely accepted, "attitudes towards gender balance are generally much more ambivalent." 224

Minimal direct advocacy on the issue of sex representation on most international courts historically may be to blame for ambivalence about the paucity of women on the bench. In discussing President Carter's historic advancement of women on the federal judicial bench in the US, Sally Kenney proposed that change occurs when people mobilize, especially strategically placed insiders collaborating with outside groups. ${ }^{225}$ Perhaps the same applies to the inclusion of women judges on the International Criminal Court. The reason the Rome Statute has a gender representativeness requirement is because groups advocated vigorously for it. $^{226}$ Interest groups argued that the ICTY, founded in the wake of over ten thousand rapes in the former Yugoslavia, should have had more women on the bench. ${ }^{227}$ They suggested that the presence of people like Navanethem

${ }^{223}$ See, e.g., SAlly KenNey, Gender \& Justice: Why WOMEN IN THE JUDICIARY REALlY MATTER (2013) (arguing that Carter's advancement of women on the federal judicial bench was driven primarily by mobilization by strategically placed insiders collaborating with outside groups).

${ }^{224}$ SELECTING INTERNATIONAL JUdGeS, supra note 20, at 48-49.

${ }^{225}$ KeNNEY, supra note 223, at 65.

226 Nienke Grossman, Sex Representation on the Bench and the Legitimacy of International Criminal Courts, 11 INT'L CRIM. L. REV. 643, 650 (2011) [hereinafter Grossman IV].

${ }^{227} I d$. 
Pillay on the ICTR made a difference in the development of international criminal law, and that it was essential that the ICC have women's voices on it, not just experts on violence against women and children. ${ }^{228}$ Arguably, the ICC has had such high representation of women judges because NGOs and sympathetic states pushed for the for the "fair representation" requirement in the statute and NGOs "made extensive efforts to bring forward the names of women who met the election requirements, particularly from those countries that had little diplomatic leverage to get one of their nationals elected. Once some of these women were nominated, NGOs vigorously lobbied states to elect them.",229

Domestic constituencies may pay little attention to the percentage of women judges on international courts due to a lack of knowledge of and interest in their activities. Simply, people are more likely to know and care about courts in their own communities than in far-flung places across the world, with little perceived significance for their daily lives. Consequently, individuals vetting, nominating and electing judges on behalf of states face little domestic political pressure to propose or vote for a diverse slate of candidates. The lack of transparency around nominations and elections also serves to shield officials from the public view on this issue. While domestic constituencies may push for the inclusion of women on domestic benches, they may be unaware that selection is even taking place for international ones.

Perhaps calls for more representative benches are beginning to grow louder, at least for some courts. More people are studying and questioning extreme sex unrepresentativeness on international commercial and investment treaty arbitral panels. ${ }^{230}$ Non-governmental organizations such as the Center for Justice and International Law, are organizing events around the selection and nomination processes at the Inter-American Court of Human Rights. Other groups, such as the International Association of Women Judges, foster networks of women judges from around the world and share information about vacancies when they are announced. On the other hand, it is rare to hear people decrying the paucity of women judges on the International Tribunal for the Law of the Sea or the WTO Appellate Body.

\section{PROPOSALS FOR REFORM}

${ }^{228} I d$.

${ }^{229}$ TERRIS ET AL., supra note 10, at 19.

${ }^{230}$ Franck et al., supra note 7; Sergio Puig, Social Capital in the Arbitration Market, 25 EuRO. J. INT'L L. 387, 401, 404-405 (forthcoming 2014). 
Opaque and closed selection procedures at the national nomination and international elections levels, political horse-trading, and a lack of advocacy around and sunlight on the issue of representativeness on the bench are likely facilitating sex unrepresentativeness on most international court benches. In light of these conclusions, what reforms to judicial selection procedures would increase sex representativeness on international benches? This Part proposes methods for enhancing openness and transparency at the national nomination and international voting levels. It also analyzes why states may, in many instances, be against what appear to be reasonable and legitimacy-enhancing reforms. Mandatory quotas or aspirational targets may be advisable should enhanced procedures fail, or as an alternative to them. The feasibility or desirability of potential reforms may vary by the court involved.

\section{A. Enhance Candidate Selection Procedures}

To improve the probability of the nomination of women as well as other non-status quo candidates for international judgeships, national selection procedures must be made more open and accessible for courts where they are currently closed and opaque. Rather than simply giving national groups or state officials completely unfettered and unguided discretion in selecting nominees, qualifications requirements and procedures to be employed at the national level should be spelled out in greater detail by the states that utilize these courts. For example, states parties could pass resolutions, like the Assembly of the State Parties to the ICC, clarifying what kinds of qualities and experiences they expect judges will have. Like the procedures for nominating judges to the European Court of Human Rights, relevant political bodies can provide examples of different procedures or "best practices" that can be utilized in the nomination and selection of candidates at the national level. These practices might include public advertisement for potential candidates, a more detailed description of the candidate evaluation process and necessary qualifications, participants in the nomination and evaluation processes, and deadlines.

Alternatively, or in addition, all states could be required to detail what standards and procedures they intend to use in their domestic nomination processes, what procedure took place, and how many nominees were considered, along with their list of nominees. This information could then be filed with the Registrar of the relevant court. The idea is that if states must draft explicit standards and procedures for international judge nominees, they are more likely to employ them. Such requirements will help to identify a broader pool of candidates and show the public, including 
interested NGOs, what procedures are followed. If nomination procedures are brought to the attention of interested members of the public, officials charged with selecting candidates are less likely simply to go with who they know and more likely to conduct a search with a more diverse and meritorious pool of candidates.

Another way to make the process more transparent is to allow nonstate actors to take part in vetting potential candidates or to require states to create national nominating commissions which represent the relevant constituencies in a particular state. If commissions are used, they should reflect the diverse makeup of the society. ${ }^{231}$ States could also create commissions composed of relevant stakeholders at the international level to vet candidates proposed by states, as the ICC, the ECHR, ECOWAS and the ECJ are currently doing to different extents. Commissions could be composed of individuals with some knowledge of the subject matter jurisdiction of the relevant court and guidance about necessary qualifications for competent judges. As suggested by the International Bar Association, such commissions could draw on the model of the United Nations Internal Justice Council as well. ${ }^{232}$ The United Nations General Assembly created the Council, composed of reputable lawyers and a small secretariat to be appointed by the United Nations Secretary General, to propose lists of qualified candidates to states for the UN tribunals charged with hearing internal staff complaints. ${ }^{233}$

Shining light on, requiring systematization of and involving more

${ }^{231}$ Some have criticized US domestic selection commissions for taking the appointments process out of the public view and for the lack of diversity among commissioners, particularly when no statutory requirement for diversity on the commissions exists. See Becky Kruse, Luck and Politics: Judicial Selection Methods and Their Effect on Women on the Bench, 16 Wisc. Women's L. J. 67, 82-3, Appendix A (2001). The American Judicature Society recommended in 2008 that commissioners be appointed or elected taking into account geographic representation and bipartisan membership, and appointing authorities are to "make reasonable efforts to ensure that the commission substantially reflects the diversity of the jurisdiction (e.g., racial, ethnic, gender, and other diversity)." Am. Judicature Soc'y, Model Judicial Selection Provisions (rev. 2008), 1. In the same vein, Ruth Cowan, a scholar of the South African judiciary questioned whether those involved in the judicial nomination process, although charged with diversifying the judiciary, might in fact be blocking the appointment of women. Cowan, supra note 49 , at s. E.

${ }^{232}$ IBA's Background Paper, supra note 208, para. 5.

${ }^{233} I d$. 
stakeholders in selection procedures is more likely to result in the consideration of a broader and more competent array of candidates because of greater public participation and accountability. Closed, opaque procedures, on the other hand, create few incentives for those choosing nominees to move beyond their own personal contact lists and to forego the benefits that may accrue to them personally by choosing people within their own networks.

Yet states may have principled reasons to reject enhanced procedures. States may prefer the opportunity to control tightly the nomination and election process for international judges rather than opening it to the light of day. Creating commissions and transparency may run counter to their understanding of the proper relationship between states and international courts more generally. Erik Voeten has identified a number of motivations which may affect how a state approaches international judicial appointments, including signaling credible commitments to a particular cause such as human rights, influencing the court's decision-making in a way that protects a state's sovereign interests or promotes an activist agenda, advancing liberal internationalist norms, and political patronage.234 Keeping the selection process primarily in the hands of individual states may allow states more effectively to pursue some of these goals. For example, at the national level, opacity and lack of procedure simplifies the nomination process and gives state officials the opportunity to grant political favors. Public calls for nominations and national selection commissions would limit a state official's ability to reward loyalists.

In addition, unfettered discretion makes it possible for states to promote candidates who will vote in line with a state's perceived interests and broader foreign policy agenda. Provided closed and opaque selection procedures, national governments may select or vote on candidates because they believe individuals will vote in a particular way should issues of importance to that state arise. For example, a large state with a powerful military may choose an ICC candidate who would interpret broadly key terms in international criminal and humanitarian law such as "necessity" and "proportionality," so that the law develops in a manner that gives the state greater flexibility in its war-waging techniques. A smaller, less powerful state might choose a candidate with a narrower understanding as a protective measure against its larger and aggressive neighbors. Hypotheticals are unnecessary to make the point. As Voeten has

234 See generally Voeten, The Politics of International Judicial Appointments, supra note 12; Erik Voeten, The Politics of International Judicial Appointments: Evidence from the European Court of Human Rights, 61 INT'L ORG. 669, 670-1 (Fall 2007). 
demonstrated, governments in favor of European integration chose more activist judges for the European Court of Human Rights. ${ }^{235}$ In the same vein, the United States and other states have taken an active role in interviewing and vetting candidates for membership on the WTO Appellate Body to ensure their consistency with their interests. ${ }^{236}$ They have de facto vetoed candidates who disagree or are perceived to disagree with them on important policy matters. ${ }^{237}$ The less power states have to nominate and elect the candidates of their choice, the less likely they are able to shape the future decisions of international courts.

Eric Posner and John Yoo might add that enhanced selection procedures promote the "independent" nature of many international courts, which may undermine their effectiveness. Posner and Yoo define "independence" as "a measure of the tribunal member's vulnerability to the state that appoints him. Tribunals composed of dependent members have a strong incentive to serve the joint interests of the disputing states." 238 Independent members, on the other hand, are less motivated to serve disputing states' interests, and morals, ideology and the interests of other states may influence their decision-making. ${ }^{239}$ Because independent judges' rulings are less likely to appease the litigating parties than dependent judges, compliance will decline, and so will the effectiveness of the Court. $^{240}$ Transparent selection procedures with screening at the international level are more likely to produce independent judges. Members of selection commissions at the international level are likely to screen out or rank lower candidates they perceive as biased toward a particular state or set of interests, so long as the commission itself is composed of individuals representing states with diverse interests.

But if a state's goals are to promote the rule of law or signal a commitment to a particular normative regime, it may prefer to appoint judges through transparent and merit-based process. Alternatively, whether states perceive adjudicators as trustees of a particular legal regime, rather than agents who merely reflect their policy preferences, may affect their disposition to more open and merit-based selection procedures. In

${ }^{235}$ Voeten, supra note 12 , at $670-71$

${ }^{236}$ Richard H. Steinberg, Judicial Lawmaking at the WTO: Discursive, Constitutional, and Political Constraints, 98 AM. J. INT'L L. 247, 264 (2004); Elsig \& Pollack, supra note 106, at 4.

${ }^{237}$ Steinberg, supra note 236, at 264.

238 Eric Posner and John Yoo, Judicial Independence in International Tribunals," 93 CALIF. L. REV. 1, 26-27 (2005).

${ }^{239} I d$. at 27.

${ }^{240} I d$. at 28 . 
distinguishing between trustees and agents in the international courts context, Karen Alter wrote,

Principals choose to delegate to Trustees, as opposed to Agents, when the point of delegation is to harness the authority of the Trustee so as to enhance the legitimacy of political decisionmaking. Trustees are (1) selected because of their personal reputation or professional norms, (2) given independent authority to make decisions according to their best judgment or professional criteria, and (3) empowered to act on behalf of a beneficiary. ${ }^{241}$

Agents, on the other hand, are expected to be loyal to and implement the decisions of the Principal. ${ }^{242}$ Screening commissions at the international level may serve to filter out Agents in favor of Trustees. They may choose judges who will interpret the law with reference to the prevailing legal discourse, professional norms and moral ideals rather than in accord with the political sensibilities of the Principal.

Open procedures at the national level and international screening or ranking of candidates for international judicial office decrease states' ability to affect substantive legal decision-making in international courts. They cannot simply choose the candidate who they expect will vote their way on a given matter. At the same time, these enhanced procedures are more likely to result in decision-making that is independent from state influence and focused on cultivating the rule of law, qualities which strengthen the legitimacy of these institutions. And it appears that such enhanced procedures coincide with greater opportunity for women, and perhaps others, to serve on international court benches.

\section{B. Aspirational Targets or Temporary Mandatory Quotas}

Enhanced procedures may not be acceptable to states, or they may not work to change the sex unrepresentative status quo. What about aspirational targets or quotas? A comparison of courts with representativeness requirements against courts without them suggests that representativeness requirements are correlated with greater numbers of women judges on the bench over time. From their establishment until mid2015 , women have occupied only $15 \%$ of slots of courts without representation requirements, as compared to $32 \%$ of slots for courts with them. While the percentage of women judges has increased over time for

${ }^{241}$ Karen J. Alter, Agents or Trustees? International Courts in their Political Context, 14 Euro. J. InT'L RELATIONS 33, 35 (2008).

${ }^{242}$ Id. at 39-40. 
both categories of courts, the overall percentage of women judges on courts with no representativeness requirement has never broken $20 \%$. It has reached $40 \%$ for courts with representativeness requirements. Consequently, the adoption of aspirational language or of mandatory targets may result in better sex representativeness on the bench. Mandatory targets could be adopted at the nomination stage, as the ECHR does, or quotas could be instituted at the voting phase, as the ICC does. This section considers the pros and cons of such measures, and ultimately concludes that, should enhanced selection procedures fail to achieve more sex representative bodies, or should states disfavor them, temporary mandatory measures are worth considering.

Concrete steps to open up international courts benches to women are not only permitted by international law, but also may be required by it. CEDAW's Article 11 specifies that "States Parties shall take all appropriate measures to eliminate discrimination against women in the field of employment in order to ensure, on a basis of equality of men and women, the same rights, in particular: ...(b) [t] he right to the same employment opportunities, including the application of the same criteria for selection in matters of employment." ${ }^{243}$ States have agreed that the use of special measures of a temporary duration may very well be appropriate to foster equality. ${ }^{244}$ As of June 2014, 188 states considered themselves to be parties to CEDAW. 245

The 1995 Beijing Declaration, subsequently adopted by the United Nations General Assembly, emphasized the importance of full participation

${ }^{243}$ CEDAW, supra note 38, art. 11.

244 The treaty also provides: “...[a]doption by States Parties of temporary special measures aimed at accelerating de facto equality between men and women shall not be considered discrimination as defined in the present Convention, but shall in no way entail as a consequence the maintenance of unequal or separate standards; these measures shall be discontinued when the objectives of equality of opportunity and treatment have been achieved." Id., art. 4(1).

${ }^{245}$ United Nations, Status of Treaties, Convention on the Elimination of All Forms of Discrimination Against Women 1, at https://treaties.un.org/Pages/ViewDetails.aspx?src=TREATY\&mtdsg_no=I V-8\&chapter=4\&lang=en (last visited June 19, 2014). A number of states have made reservations to CEDAW which likely conflict with its object and purpose, and therefore, would presumably render them non-parties, but they nonetheless consider themselves parties. See Vienna Convention on the Law of Treaties art. 19, opened for signature May 23, 1969, 1155 U.N.T.S. 331. 
in decision-making and access to power. ${ }^{246}$ In the Beijing Platform, states agreed to

Commit themselves to establishing the goal of gender balance in governmental bodies and committees, as well as in public administrative entities, and in the judiciary, including, inter alia, setting specific targets and implementing measures to substantially increase the number of women with a view to achieving equal representation of women and men, if necessary through positive action, in all governmental and public administration positions. ${ }^{247}$

With respect to United Nations bodies, states agreed to "[a]im at gender balance in the lists of national candidates nominated for election or appointment to United Nations bodies, specialized agencies and other autonomous organizations of the United Nations system, particularly for posts at the senior level. ${ }^{248}$ Other global and regional treaties authorize and promote the use of temporary measures to ensure equality of opportunity and non-discrimination, including the International Labor Organization's Convention No. $111^{249}$ and the Protocol to the African Charter on Human and People's Rights on the Rights of Women in Africa. ${ }^{250}$

${ }^{246}$ Fourth World Conference on Women, Beijing Declaration and
Platform for Action, para. 13 (1995), at
http://www.un.org/womenwatch/daw/beijing/pdf/BDPfA\%20E.pdf.

"Women's empowerment and their full participation on the basis of equality in all spheres of society, including participation in the decision-making process and access to power, are fundamental for the achievement of equality, development and peace." Id.

${ }^{247}$ Id., para. 190(a).

${ }^{248} I d$., para. $190(\mathrm{j})$.

${ }^{249}$ ILO Convention No. 111 specifies that states parties must "declare and pursue a national policy designed to promote... equality of opportunity and treatment in respect of employment and occupation, with a view to eliminating any discrimination in respect thereof," and it authorizes "special measures of protection or assistance" to this end. Convention Concerning Discrimination in Respect of Employment and Occupation, ILO Convention No. 111 art. 2, June 25, 1958, 362 U.N.T.S. 31. 172 states have ratified the treaty. Ratifications of C111, http://www.ilo.org/dyn/normlex/en/f?p=1000:11300:0::NO:11300:P11300_ INSTRUMENT_ID:312256 (last visited June 26, 2014).

${ }^{250}$ States "shall... take corrective and positive action in those areas where discrimination against women in law and in fact continues to exist." 
Interestingly, aspirational and mandatory targets have become more broadly accepted in the domestic political context in recent years, and they exist in over one hundred countries in various forms. ${ }^{251}$ For example, France requires all political parties to list equal numbers of men and women in most elections, ${ }^{252}$ Rwanda's Constitution specifies that at least $30 \%$ of each decision-making body must be composed of women. ${ }^{253}$ Argentina mandates that women must be placed in electable positions on party lists. ${ }^{254}$ The Iraqi Constitution aims for at least one-quarter of the Council of Representatives to consist of women. ${ }^{255}$ At least a few states have adopted quotas for the judiciary as well. The Transitional Constitution of South Sudan states that " $[t]$ here shall be a substantial representation of women in the Judiciary having regard to competence, integrity, credibility and impartiality. ${ }^{, 256}$ Belgium recently adopted a quota for women on its constitutional court. ${ }^{257}$

In response to low participation of women on European corporate boards and low growth rates over time, some legislatures have instituted mandatory minimum requirements. ${ }^{258}$ Norway instituted a $40 \%$ of either sex

Protocol to the African Charter on Human and Peoples' Rights on the Rights of Women in Africa art. 1, adopted July 11, 2003, http://www.africaunion.org/root/au/Documents/Treaties/Text/Protocol\%20on\%C20the\%C20 Rights\%C20of\% 20Women.pdf.

${ }^{251}$ Susan Franceschet et al., Conceptualizing the Impact of Gender Quotas, in THE IMPACT OF GENDER QUOTAS 3 (Susan Franceschet et al., eds., 2012).

${ }^{252} I d$. at 27.

Constitution of Rwanda, art. 9(4), at http://www.rwandahope.com/constitution.pdf (last visited June 27, 2014).

${ }_{255}^{254}$ Franceschet et al., supra note 251, at 44-45.

255 Constitution of Iraq, art. 49, available at http://iraqinationality.gov.iq/attach/iraqi_constitution.pdf.

256 Constitution of South Sudan, art. 123(6) at http://www.goss.org/docs/Transitional\%20Constitution\%20of\%20South\%2 OSudan.pdf (last visited June 27, 2014).

${ }^{257}$ Loi spéciale portant modification de la loi du 6 janvier 1989 sur la Cour constitutionnelle (1), art. 12 (April 15, 2014)( "La Cour se compose de juges de sexe différent, tant en ce qui concerne les juges visés au $\S 1 \mathrm{er}, 1 \mathrm{o}$, que ceux visés au $\S 1 \mathrm{er}, 2 \mathrm{o}$. Elle compte au moins un tiers de juges de chaque sexe.")

${ }^{258}$ European Commission, Director General for Employment, Social Affairs and Equal Opportunities, More women in senior positions: Key to economic stability and growth 44 (January 2010). The percentage of 
requirement on boards of all privately owned public limited companies, and non-compliance can result in penalties and even dissolution of the company. ${ }^{259}$ Since the institution of the quota, participation on corporate boards rose from $25 \%$ in 2004 to $42 \%$ in 2009. ${ }^{260}$ In March 2007, Spain passed a law requiring public companies and other large firms with more than 250 employees to develop plans to promote equal participation on boards and to try to achieve $40 \%$ participation of each sex within eight years. $^{261}$ In late 2010, France adopted a law requiring listed companies and companies with 500 or more employees and revenues over 50 million euros to appoint $40 \%$ women on boards within six years. ${ }^{262}$ The Netherlands, Italy, and Belgium also adopted quota laws. ${ }^{263}$ Austria, Denmark, Finland, France, Germany, the Netherlands, Poland, Spain, Sweden, and the United Kingdom make reference to gender in corporate governance codes. ${ }^{264} \mathrm{~A}$ study by the European Commission's Network on to Promote Women in Decision-making in Politics and the Economy asserted that "a wave of quota debates is sweeping over Europe, creating more awareness with the public and putting pressure on companies and governments to make fast and fundamental changes in the representation of women in decisionmaking."265 In November 2013, the EU Parliament voted to require European companies to hire $40 \%$ women for corporate board positions by $2020 .^{266}$ The issue of gender diversity on corporate boards and possible remedies including quotas has been discussed in non-European countries as well, including South Africa and Australia. ${ }^{267}$

women on Europe's corporate boards grew less than 3\% points, to a total of $10.9 \%$, from 2003-2009. Id.

${ }^{259} I d$. at 45.

${ }^{260}$ Id. (internal citation omitted).

261 European Commission's Network to Promote Women in Decisionmaking in Politics and the Economy, Working Paper, The Quotainstrument: different approaches across Europe 12 (June 2011),

${ }^{262} I d$.

${ }^{263}$ Id.

${ }^{264} \mathrm{Id}$. at 13.

265 Id. at 15.

266 European Parliament News, Press Release, $40 \%$ of seats on company boards for women, Nov. 20, 2013, at http://www.europarl.europa.eu/news/en/news-

room/content/20131118IPR25532/html/40-of-seats-on-company-boardsfor-women (last visited June 27, 2014).

267 See Jean J. du Plessis et al., Board Diversity or Gender Diversity? Perspectives from Europe, Australia and South Africa, 17 DEAKIN L. REV. 
Despite the now widespread use of quotas at the political level, on corporate boards, and to a lesser extent, in judiciaries, counter-arguments to the use of mandatory quotas exist. It is more difficult to find arguments against aspirational targets. Aspirational targets simply point out to nominators that sex representation is a worthwhile goal. They express the community of relevant states' values about who should be represented on the bench as a whole, but they impose no requirement to reject or accept a candidate based on sex. From a political standpoint, aspirational language may show domestic political constituencies that their states have, at least, a political commitment to sex representation. (One could imagine a more widespread use of such language to encompass other groups as well, such as to include indigenous people or people of minority status within their own states.) Aspiring to a fair representation of the sexes led to a dramatic difference on the ICTY and the ICTR between the percentage of women serving as ad litem (aspirational sex representativeness language) as compared to permanent judges (no such language). Women served in much higher percentages on the ad litem bench. ${ }^{268}$ On the other hand, women have made up only $18 \%$ of the African Court on Human and Peoples' Rights bench. Nonetheless, there are many other courts with even lower percentages of women on the bench in June 2015, including ITLOS, IACHR, ECOWAS, the WTO Appellate Body, and the ICTY's permanent judges.

Some might argue that targets of any kind are not worthwhile if they do not result in "substantive representation," or the promotion of women's concerns. ${ }^{269}$ The jury is still out on whether sex representativeness affects international court decision-making, although there is some evidence that it may make a difference in at least some cases. A 2007 study on the role of gender in sexual assault decisions of international criminal tribunals excluded the International Criminal Tribunal for Rwanda in part because there were "too few [women judges] to conduct empirical analysis..."270 The same study found that ICTY panels with female judges imposed more severe sanctions on defendants who assaulted women, while male judges imposed more severe sanctions on defendants who assaulted men. ${ }^{271}$ Another study showed that women judges were much more likely to rule in favor of jurisdiction in cases under the auspices of the International Centre

207 (2012) (discussing debates and initiatives on corporate board diversity). ${ }^{268}$ See supra figures $9 \& 10$.

${ }^{269}$ Franceschet et al., supra note 251, at 8.

${ }^{270}$ King \& Greening, supra note 25, at 1050.

${ }^{271} I d$. at 1065-66. 
for the Settlement of Investment Disputes than men. ${ }^{272}$

A number of studies have sought to understand the relationship between gender and judging in the United States, scholarship which may help to illuminate the gender effect of judging in international courts, in the absence of additional international data. Although many studies show a limited or non-existent effect of gender on judging, cases involving family law and discrimination appear to be an exception. ${ }^{273}$ One study found that a sex discrimination plaintiff was 10 percentage points less likely to prevail if the judge was male, and when a woman was present on a panel deciding such a case, men were more likely to rule in favor of the plaintiff. $^{274}$ Another study showed that asylum applicants randomly assigned to women judges were $44 \%$ more likely to prevail than those facing male judges. ${ }^{275}$

Anecdotal evidence at the international level may also be instructive in understanding that a gender diverse bench makes a difference. A number of female judges have made statements implying that their experiences as women gave them a particular sensitivity in certain cases. These include former D.C. Court of Appeals and International Criminal Tribunal for the Former Yugoslavia Judge Patricia Wald, former International Criminal Court Judge Navenathem Pillay, and former Inter-American Court of Human Rights Judge Cecilia Medina. ${ }^{276}$ For example, Judge Wald wrote:

...being a woman and being treated by society as a woman can be a vital element of a judge's experience. That experience in turn can subtly affect the lens through which she views issues and solutions.... A judge is the sum of her experiences and if she has suffered disadvantages of discrimination as a woman, she is apt to be sensitive to its subtle expressions or to paternalism. ${ }^{277}$

${ }^{272}$ Waibel \& Wu, supra note 26 , at *34-35.

${ }^{273}$ See Sally J. Kenney, Thinking about Gender and Judging, 15 INT'L J. Legal PROF. 87, 96-101 (2008); Kate Malleson, Justifying Gender Equality on the Bench: Why Difference Won't Do, 11 FEMINIST LEGAL STUDIES 1, 7 (2003).

274 Christina L. Boyd, Lee Epstein, \& Andrew D. Martin, Untangling the Causal Effects of Sex on Judging, 54 AM. POL. SCI. 389, 390, 406 (2010).

275 Jaya Ramji-Nogales, Andrew I. Schoenholtz, \& Phillip Schrag, Refugee Roulette: Disparities in Asylum Adjudication, 60 StAN. L. ReV. 295, 342 (2007).

${ }^{276}$ Grossman IV, supra note 226, at 647-48.

${ }^{277}$ Wald, Six Not-So-Easy Pieces: One Women Judge's Journey to the Bench and Beyond, supra note 29, at 989. 
She has also pointed to five different major gender-crime precedents issued when at least one woman sat on the bench. ${ }^{278}$ Judge Pillay suggested that although women do not "decide in a different way," they have a "particular sensitivity and understanding about what happens to people who are raped."279 Former Inter-American Court Judge Cecilia Medina Quiroga posited that her womanly perspective changed the reparations outcome in a case involving a massacre and rape in Guatemala. ${ }^{280}$

National judges and lawyers from all over the world have made similar points. For example, United States Justice Ruth Bader Ginsburg, while expressing doubts about the accuracy of studies on gender and judging, suggested that "the presence of women on the bench made it possible for the courts to appreciate earlier than they might otherwise that sexual harassment belongs under Title VII."281 Madame Justice Bertha Wilson, the first woman on Canada's court of last resort asserted that for entire areas of the law, "there is no uniquely feminine perspective," but in others, "a distinctly male perspective is clearly discernible..." 282 In the same vein, Lady Baroness Hale, the sole woman ever to have served on the United Kingdom's highest court, posited that women bring "different perceptions to the task of fact-finding - which is what most judges do much of the time." ${ }^{283}$ A European Commission survey of male and female judges and other legal professionals found that, in cases involving violence against women or children, family issues, and sometimes sex discrimination, "it is recognized (mainly by the women interviewed that gender does have an influence." 284 Although she thought gender made little difference most of the time, an Israeli judge pointed out a number of instances where she thought it did make a difference, including commercial cases and cases

${ }^{278}$ Wald, What do Women Want from International Criminal Justice?

To Help Shape the Law, supra note 29.

${ }^{279}$ TERRIS ET AL., supra note 10, at 48.

${ }^{280} \mathrm{Id}$. at $186-87$.

${ }^{281}$ Emily Bazelon, The Place of Women on the Court, New York Times MM22 (July 12, 2009) (interviewing Justice Ruth Bader Ginsburg).

282 Bertha Wilson, Will Women Judges Really Make a Difference? 28

OSGOOdE HALl L. J. 507, 515 (1990).

${ }^{283}$ Brenda Hale and Rosemary Hunter, A Conversation with Baroness Hale, 16 FEMINIST LEGAL STUdiEs 237, 245 (2008).

${ }^{284}$ Miriam Anasagasti and Nathalie Wuiame, Women and DecisionMaking in the Judiciary in the European Union 8, 23-4 (European Commission 1999). 
involving sexual assault. ${ }^{285}$

Some may argue that the presence of both men and women may matter for some but not all courts. For example, sex representativeness may be important on international criminal and human rights courts because male and female judges may perceive gender-biased violence in different ways, and victims may feel less comfortable relating such stories to a unisex court. $^{286}$ Further, for human rights courts in particular, some constituencies will question the values and impartiality of a human rights court where half of humanity is missing from the bench. If women judges relate to rape or crimes of violence against women in a different way than men, then both are necessary on the bench for impartiality. On the other hand, a mixed bench may be unnecessary or irrelevant for a court that interprets the Law of the Sea or trade agreements. If there is no difference in substantive outcome, why is important to have a female or male judge on the Law of the Sea Tribunal or on the WTO Appellate Body?

The presence of both sexes on the bench is important, regardless of subject matter or whether a unique feminine or male perspective exists on a particular factual or legal issue. International courts exercise public authority by interpreting and shaping international law. ${ }^{287}$ Democratic values such as representation provide meaningful justification for the exercise of such authority. ${ }^{288}$ In essence, those affected by decision-making should play some role in the making of those decisions. As half of the world, women are equally impacted by the decisions of international courts.

285 Hana Evenor, Women on the Bench 93-95, in WOMEN IN LAW (Shimon Shetreet, ed. 1998).

${ }^{286}$ Grossman IV, supra note 226, at 647-48.

287 TERRIS ET AL., supra note 10, at 115-17 (discussing a number of different examples, ranging from the European and Inter-American human rights courts' contribution to the development of human rights law "far beyond what the original drafters [of the respective conventions] might have conceived," to the role of the European Court of Justice in European integration, to the WTO Appellate Body's inclusion of other areas of international law within its jurisdiction); see also von Bogdandy \& Venzke, supra note 33, at 979, 979 (stating that international judicial decisions influence future decisions); Grossman III, supra note 33, at 68-76 (explaining how international courts influence the development of law and politics).

288 Gráinne De Búrca, Developing Democracy Beyond the State, 46 Colum. J. Transnat'L L. 221, 226-27 (2008). Armin von Bogdandy and Ingo Venzke, On the Democratic Legitimation of International Judicial Lawmaking, 12 GER. L. J. 1341, 1343 (2011). 
Even if men and women were identical in their identification and interpretation of relevant facts and application of law, it would still be problematic to have all female benches or all male benches. Furthermore, if these groups are identical in their reasoning and approach to legal analysis, how can we justify the systematic exclusion of one of them?

Opponents of electoral quotas have argued that they "facilitate access for 'unqualified' women with little interest in promoting women's concerns" and "reinforce stereotypes about women's inferiority as political actors." 289 Similar arguments could be made concerning mandatory judicial quotas. If women are less qualified and replace more qualified male candidates, their presence may detract from the authority of international courts, and therefore, be ill-advised. Less incentive exists to respect and comply with the decisions of international courts if the judges are not of high caliber. Because of the small number of international judge positions in the world - a few hundred at most - arguments about qualifications are more difficult to make in this context than in domestic political elections. Surely there are three women qualified to sit on the Inter-American Court of Human Rights, the WTO Appellate Body and the ECOWAS Court. And there must be more than only one woman in the entire world qualified to serve on the Law of the Sea Tribunal. Further, as described above, it is not at all clear that merit is what motivates many judicial appointments in the first place. ${ }^{290}$ In other words, the argument that women are "unqualified" has little purchase when judicial nominees are often selected to reward political loyalty or because of their relationships with nominators.

Another counter-argument to mandatory targets is that its beneficiaries may be perceived as somehow inferior or less capable than their male peers, even if they are equally or even more qualified. Alternatively stated, women would not be in the courtroom but for the quota. A quota and the corresponding perceived drop in the qualifications of judges is dangerous for the authority of the court. The problem is that current selection procedures appear to be keeping qualified women off the bench, not that a quota would put unqualified women on it. Put otherwise, it is simply inconceivable that no French or Russian woman is qualified to serve as a permanent international judge. As for a failure to promote "women's concerns," should men's presence on the bench be justified on

${ }^{289}$ Franceschet et al., supra $\mathrm{n} .251$, at 3.

290 See, e.g., Selecting InTERNATIONAL JUdGeS, supra note 20, at 77, 95, 102 ("Success depends to a large extent on vote trading and campaigning..."); Booth \& Sands, supra note 73; TERRIS ET AL., supra note 10, at 34 ; Bohlander, supra note 207, at 354; IBA's Background Paper, supra note 208, at para. 6 . 
the basis of their ability to promote "men's concerns"? Is this a litmus test to be applied to all judges, or just female ones? Furthermore, the presence of diversity in leadership is important for other reasons as well, such as nondiscrimination in employment opportunity, opening doors to other previously excluded groups and democratic legitimacy.

If states decide they want women on the bench in greater numbers, but do not want to give up tight control over who ultimately gets nominated and selected, they may prefer quotas or aspirational targets over more sweeping reforms to national nomination and international election procedures. More sex representative benches may be more impartial, if and when men and women judge differently, or be perceived to be more impartial, even if men and women do not differ in their decision-making. And more balanced benches would confer greater democratic legitimacy on these courts, simply because more of humanity would be on the bench. Since states have already agreed to quotas or aspirational targets for the International Criminal Court, the European Court of Human Rights, the African Court on Human and Peoples' Rights, and to a lesser extent in the ICTY and the ICTR, they may be willing to do so for more international courts. On the other hand, states may choose to craft more transparent and merit-driven selection procedures, which appear to help open the courthouse doors to women judges, possibly rendering quotas unnecessary.

\section{CONCLUSION}

Almost a quarter century after feminist approaches made their way into international legal scholarship, women continue to be present in paltry numbers in many international institutions, including international courts. While women do occupy more seats today on most courts than 24 years ago, on courts with no representation requirements, men usually take up at least $80 \%$ of the bench.

A smaller pool of available candidates is an unpersuasive and problematic justification for the status quo. First, the data does not support it. States with higher percentages of women lawyers have not necessarily appointed more women as the pool has grown. Some states with lower percentages of women lawyers appear to appoint more women to the bench than those with higher percentages. And the percentage of women judges has dropped on some courts, or appears frozen at one or two women on the bench, although it is reasonable to assume the pool has grown over time. Women occupied the same number of seats on the IACHR in June 2015 as they did in 1991. The percentage of female ad litem judges has dropped dramatically on both the ICTY and the ICTR over time. Only one woman has ever served on ITLOS's 21-member bench in almost twenty years, and 
the African Court has never exceeded two women on its eleven member bench.

Second, in many cases, merit does not appear to be driving the judicial selection process in the first place. If merit is not at the heart of the process, then there is no reason to suppose that the pool of women candidates is any smaller than the pool of male ones, or that naming women would result in a less meritorious bench. Third, to the extent the pool appears smaller for international courts than domestic ones, glass ceilings and discrimination in the domestic context are at least partly at fault. Declining to promote more women on this basis merely recreates and reinforces the glass ceiling at the international level. Fourth, the number of judicial slots available per year is quite low; a huge pool of women candidates is not necessary to achieve a balanced bench.

Compelling reasons exist to seek a balanced representation of the sexes on international court benches. Not only does appointing more women create more equitable employment opportunities for women who seek to become international judges, but also, it can create important ripple effects. These include greater employment opportunities for women at the domestic level and as counsel before international courts, in addition to new mentorship opportunities and perhaps greater intent to participate in international legal affairs among girls and women. ${ }^{291}$ Finally, as previously described, greater balance on the bench will strengthen courts' normative, sociological and democratic legitimacy.

States may choose from different options for achieving a more balanced bench. These include more transparency and rigor in selection procedures at the national nomination and international election levels, as well as participation by a broader array of stakeholders. Such measures would reduce both the likelihood and perception of bias and cronyism in judicial selection, as well as push nominators to move beyond their own contact lists and encourage a more diverse slate of individuals to apply. Aspirational statements concerning sex representativeness may also be useful in bringing attention to the issue of fair representation and in encouraging states to nominate and vote for female candidates. Finally, if these steps do not achieve sex representative benches, temporary mandatory quotas may be necessary to ensure that women get a fair opportunity to serve on international court benches.

The problem is clear. The time has come to fix it.

${ }^{291}$ See, e.g., Wolbrecht \& Campbell, supra note 34. 